\title{
DIGITIZING AND CATALOGUING DANCE COLLECTION DANSE'S VHS TAPE
} COLLECTION

by

Chelsea Elizabeth Keen, BA, McGill University, 2013.

\author{
A Thesis Project \\ presented to Ryerson University \\ in partial fulfillment of the \\ requirements for the degree of \\ Masters of Arts \\ in the Program of
}

Film and Photography Preservation and Collections Management

Toronto, Ontario, Canada, 2015

(C) Chelsea Elizabeth Keen 2015 
I hereby declare that I am the sole author of this thesis. This is a true copy of the thesis, including any required final revisions, as accepted by my examiners.

I authorize Ryerson University to lend this thesis to other institutions or individuals for the purpose of scholarly research.

I further authorize Ryerson University to reproduce this thesis by photocopying or by other means, in total or in part, at the request of other institutions or individuals for the purpose of scholarly research.

I understand that my thesis may be made electronically available to the public. 


\begin{abstract}
This thesis is an applied digitization and cataloguing project for Dance Collection Danse (DCD). The collection consists of sixteen dance performance recordings on VHS which were created by DanceWorks, a Toronto-based presenter of independent dance choreographies, and given to DCD by Mimi Beck, Director of DanceWorks. The objectives for this project included: digitizing the VHS recordings, cataloguing the VHS tapes using the Canadian Integrated Dance Database (CIDD), and conducting research on topics related to dance video preservation.

This thesis is divided into two parts: a research paper and a catalogue. The research paper discusses: the history of DanceWorks and DCD, the hurdles associated with trying to preserve VHS tapes, theories debating the value of preserving dance on video, and characteristics of the CIDD cataloguing software. Part two includes screenshots of the sixteen catalogue records created using the CIDD.
\end{abstract}




\section{Acknowledgements}

A special thanks goes to Amy Bowring at Dance Collection Danse for being the most thorough and resourceful first reader anyone could ask for. You have been so generous with your time and energy and you really made this thesis possible (especially since you wrote most of the secondary sources!). I'd also like to thank all the staff at Dance Collection Danse for letting me use their resources, as well as all the staff at DanceWorks for allowing me the privilege of working with their dance performance recordings. Another special thanks goes to Alex Anderson for being a dedicated second reader and the most fantastic employer. And to Gerda Cammaer who steered me to this wonderful project! You are all amazing women, thank you for being such phenomenal and inspiring mentors.

I would also like to thank everyone in the Image Arts Department for their effort and devotion to the new Film stream of the FPPCM program. I think we've paved the way for something great! 


\section{Dedicated to}

Mom, Dad, Auntie Kare, Sam, Andrea \& Bo

who have always been loving and supportive...

even when I'm the worst.

And to my extended family,

Alex Jokinen, TJ Alston and Stacey Turner (plus Fionntàn!).

You guys are the best. Cheers! 


\section{Table of Contents}

List of Figures vii

Part 1: Research Paper $\quad 1$

$\begin{array}{ll}\text { Introduction } & 1\end{array}$

$\begin{array}{ll}\text { Literature Review } & 5\end{array}$

Chapter 1: Background on DanceWorks and Dance Collection Danse 11

$\begin{array}{ll}\text { Chapter 2: Preservation Issues } & 15\end{array}$

Chapter 3: Debating the Value of Preserving Dance on Video 21

Chapter 4: Cataloguing the VHS Tapes Using CIDD 27

$\begin{array}{lr}\text { Conclusion } & 29\end{array}$

$\begin{array}{ll}\text { Appendix } & 30\end{array}$

$\begin{array}{ll}\text { Part 2: Catalogue } & 34\end{array}$

$\begin{array}{ll}\text { Bibliography } & 50\end{array}$ 


\section{List of Figures}

Figure 1. Reproduction of a still from the VHS tape labelled 5.1 DW 38; shows how the videographer panned the camera in order to place the dancer in the middle of the screen.

Figure 2. Reproduction of a still from the VHS tape labelled 10.1 DW 43; demonstrates VHS tape degradation as a blue strip of colour runs horizontally across the image.

Figure 3. Reproduction of a still from a VHS tape labelled 18.3 DW 54; shows how the image blacks out at some points on the VHS tape.

Figure 4.1 Reproduction of a still from the VHS tape labelled 1.1 DW 25; shows a relatively close-up shot of a dancer on stage.

Figure 4.2 Reproduction of a still from the VHS tape labelled 27.10 DW 63; shows a relatively distant shot of the dancers on stage. 


\section{Part 1: Research Paper}

\section{Introduction:}

This thesis is an applied digitization and cataloguing project for Dance Collection Danse (DCD), an archives and research centre for Canadian theatrical dance history. ${ }^{1}$ Currently, DCD has a collection of over 2000 moving image recordings. Within that collection, there are approximately 240 deteriorating dance performance recordings on VHS, 1/2 inch and 3/4 inch tape from the DanceWorks Portfolio (made between 1980 and 2000). As per DCD's viewing policy, only digital versions of the analog recordings may be accessed. Initially uncatalogued and not yet digitized, the contents of the videos were inaccessible to DanceWorks' staff and outside researchers. For the scope of this thesis, I have focused on digitizing (for preservation) and cataloguing only the VHS tapes in DCD's possession.

\section{About the Collection}

The performances on these VHS tapes were all presented and recorded by DanceWorks, a Toronto-based dance presenter. Some tapes are of final performances while others are anniversary celebrations and rehearsals. A variety of dance styles (ballet, contemporary and tap) are presented at different venues around Toronto: Winchester Street Theatre, St. Lawrence Hall, and the Everett Dance Theatre (now named Everett Company Stage School). Some notable performers on the recordings are Tassy Teekman, Susan McNaughton, Mimi Beck, Pierre-Paul Savoie, Bill Coleman, and Judith Marcuse. While the tapes are predominantly records of dance, some tapes also include musical (band) performances and dramatic monologues. Exact details about the context of each production are available in the cataloguing portion of the assignment.

\footnotetext{
1 Bowring, Amy. "Dance Collection Danse: Canada's Largest Archive and Research Center for Theatrical Dance History." Dance Chronicle 34, no. 2 (2011): 276.
} 
Generally speaking, the recordings are set-up such that one camera records the activity on stage from the middle-back of the room as the videographer selectively zooms in and pans the stage to follow the dancers (see Figure 1). As outlined by a study of dance collections in Canada, this 'type' of dance record can be distinguished as "a systemic documentation in real time of complete performances to serve as a record of both the choreography and the performance, where the production values of the recording are driven by the facilities and capabilities of the performance site."

\section{Why does the collection merit our attention?}

The VHS tapes merit our attention because they are deteriorating. Many of the VHS tapes demonstrate colour banding, which means there is a blue strip at the top of the image, throughout the entire recording or at certain moments (see Figure 2). Many of the tapes also exhibit a rainbow colour strip that runs diagonally at (some but not all) corners of the image (see Figure 3). While it appears as though all the tapes have suffered from colour fading, this cannot be determined because the original quality of the recording is unknown. However, the colour banding and image "blackouts" (see again Figure 3) that occur throughout the tapes do suggest that the magnetic tape has deteriorated to some degree. Despite some degradation, all tapes are playable and the recorded content is discernible.

\footnotetext{
2 Rowat, Theresa. "Study of dance collections in Canada." Commissioned by the Dance Section of the Canada Council for the Arts, with the participation of the Department of Canadian Heritage (Arts and Heritage Sector). Login:danc/se circulation draft. 2000. 9.
} 


\section{Why is the collection important to preserve?}

Dance is an ephemeral art form, which, as Marcia Siegal states, “...exists at a perpetual vanishing point"3 and the DanceWorks VHS recordings are a way of viewing the dance performances without ever having attended the show. More specifically, these recordings document the history of DanceWorks and their performances between the eighties and nineties. Since DanceWorks has become Toronto's leading presenter of independent dance ${ }^{4}$, these tapes reflect the history of one of Toronto's cultural contributors.

This collection is also important to preserve because it documents performances by notable Canadian dancers and choreographers. For example, the tapes include dances by Pierre-Paul Savoie, Judith Marcuse, Bill Coleman and Jennifer Mascall, all of whom have been recognized for their contributions to the discipline of dance. Here is a brief summary of their accomplishments: Pierre-Paul Savoie founded PPS danse in 1989, a prominent contemporary dance company in Quebec ${ }^{5}$; Judith Marcuse created Judith Marcuse Projects in 1980, a not-forprofit issue-based arts company that does work in the discipline of dance ${ }^{6}$; Bill Coleman is cofounder and artistic co-director of Coleman Lemieux \& Compagnie, a Toronto dance company ${ }^{7}$; and Jennifer Mascall started her own company, Mascall Dance, in 1989. ${ }^{8}$ Of these dancers and choreographers, all of them have been awarded the Jacqueline Lemieux Prize by the Canada

\footnotetext{
3 Siegel, Marcia B. "Introduction." At the Vanishing Point: A Critic Looks at Dance. New York. Saturday Review Press, 1972.

4 "DanceWorks - About I Background." DanceWorks. Accessed February 1, 2015.

5 "The Company - PPS Danse." PPS Danse. 2015. Accessed July 28, 2015.

6 "Judith Marcuse Projects." Judith Marcuse Projects I ICASC. 2013. Accessed July 28, 2015.

7 "Bill Coleman." Coleman Lemieux Compagnie. 2013. Accessed July 28, 2015.

8 "Jennifer Wootton Mascall." The Canadian Encyclopedia. Accessed July 28, 2015.
} 
Council. The prize was given to Jennifer Mascall in $1982^{9}$, Pierre-Paul Savoie in $1996^{10}$, Bill Coleman in $2002^{11}$ and Judith Marcuse in 2009.12 The acknowledgement of these artists' contribution to dance in Canada provides incentive for DCD to salvage any recordings of their performances.

\section{Action Taken}

In order to address concerns related to preservation and access, I have digitized sixteen VHS tapes in the collection and catalogued all of them. The tapes have been digitized using Ryerson University's Sony conversion equipment and a program called Honestech VHS to DVD 5.0 Deluxe. This way, the recorded content on the VHS tapes has been salvaged and researchers can now access the content via digital video. Once digitized, the files were saved on an external hard drive and transferred to both DCD and DanceWorks. I catalogued twenty of the VHS tapes using Dance Collection Danse's database, the Canadian Integrated Dance Database (CIDD). By cataloguing the VHS tapes, the collection has been made searchable in CIDD and therefore more accessible to researchers.

In total, my thesis project includes the digitization of sixteen VHS tapes, a catalogue of those sixteen VHS tapes and a four-chapter paper discussing: the history of Dance Collection Danse and Danceworks, issues surrounding the preservation of VHS tapes, the value (or lack thereof) in attempting to document and preserve dance on video, and a descriptive background on the characteristics of the CIDD.

\footnotetext{
9 “Jennifer Wootton Mascall." The Canadian Encyclopedia.

10 "PPS Danse." The Canadian Encyclopedia. Accessed July 28, 2015.

11 "Bill Coleman." Coleman Lemieux Compagnie.

12 "Judith Rose Marcuse." The Canadian Encyclopedia. Accessed July 28, 2015.
} 


\section{Literature Review:}

This literature review is divided into three sections. The first discusses the scholarship related to the difficulties of preserving audiovisual materials and dance heritage in Canada. The second section surveys the theoretical literature that considers the value and limitations of preserving dance on video. The third section discusses the resource I used to complete the cataloguing portion of the thesis project.

\section{Preservation Obstacles}

My discussion of issues related to preserving the VHS tape collection is divided into two topics: the sensitivity of magnetic tape to environmental conditions and the lack of resources available for small dance archives to store their audiovisual materials properly. To explain the science of magnetic tape degradation, I referred to research conducted by the Image Permanence Institute, which was prepared as a report to the National Endowment for the Humanities Division of Preservation and Access in 2006. Based on laboratory testing, the report includes a comprehensive analysis of the specific environmental conditions that lead to magnetic tape degradation as it explains the hydrolytic chemical reaction catalyzed by high temperatures and high relative humidity. ${ }^{13}$ The Canadian Conservation Institute's (CCI) web site also gives detailed information and suggestions regarding the ideal storage conditions for magnetic media. Ultimately, the CCI suggests that cold storage facilities with low relative humidity are optimal environments for the preservation of VHS tapes. ${ }^{14}$

\footnotetext{
13 "The Preservation of Magnetic Tape Collections: A Perspective." National Endowment for the Humanities Division of Preservation and Access. December 22, 2006. Accessed April 1st, 2015.

14 "Agent of Deterioration: Incorrect Relative Humidity." Canadian Conservation Institute. Accessed April 1st, 2015.
} 
To illustrate why smaller archives do not have sufficient funds for cold storage facilities, the source I cite most frequently is a study about the status of dance collections in Canada titled Study of Dance Collections in Canada by Theresa Rowat, a consulting archivist and heritage policy analyst. The research was conducted between August 1999 and May 2000 for the Dance Section of the Canada Council for the Arts, with the participation of the Department of Canadian Heritage. According to Rowat's research, dance heritage organizations do not receive adequate funding because dance documentation is marked by two "notable absences". ${ }^{15}$ First, dance documentation does not produce a primary record: choreography cannot be translated into an artifact that is easily contained by archivists, librarians or museum workers. Second, dance documentation does not lend itself to exhibition like other media (paintings at museums or films at cinematheques, for example). Since the live performance is the desired experience, this study argues that the public views supporting institutions with dance collections as less of a priority. ${ }^{16}$ In general, the study concludes that the dance discipline is underrepresented by archives. Government-sponsored archives focus on government records leaving little funds for private sector and non-traditional records such as dance. ${ }^{17}$ For example, the document refers to DCD as an institution that is under-funded because it does not fall under the umbrella of a sponsoring organization (e.g., government). In addition to not receiving plentiful funding, this study also concludes that dance video collections require extensive and costly care, especially since some

\footnotetext{
15 Rowat, Theresa. "Study of dance collections in Canada." 6.

16 lbid. 6 .

17 Ibid. 13.
} 
video materials are rapidly deteriorating and/or do not have accompanying playback equipment. ${ }^{18}$

Also integral to my research is a report prepared for the Dance Advisory Committee of the Canada Council for the Arts. The document was created by Theresa Rowat. Her report chronicles the dance heritage activities that occurred from 1999-2003 and includes Rowat's perspective on the status of collections management in the Canadian dance heritage community. Rowat notes that all dance heritage activities are organized by the dance community and initiated through the dance community's funding contexts. ${ }^{19}$ Professional and scholarly institutions, she argues, are unconcerned with dance heritage. However, it is her opinion that dance collections must also be the concern of the arts, heritage and education sectors. ${ }^{20}$ Her goal was to endow heritage institutions with a sense of responsibility toward dance collections and dance documentation. Her work at the time indicated that she wanted to initiate a dialogue between the dance community and the heritage institutions that she thought should be supporting dance. ${ }^{21}$ After reviewing the history of dance heritage activism, Rowat makes suggestions for the future of dance preservation: identify a network for dance preservation across Canada, ensure documentation for future dance creation in Canada and address the preservation management needs for Canadian dance heritage materials created before $1990 .{ }^{22}$

\footnotetext{
18 Rowat, Theresa. "Study of dance collections in Canada." 10.

19 Rowat, Theresa. "Dance Heritage Review and Current Status." Prepared for the Dance Advisory Committee of the Canada Council for the Arts, May 28 2003. 1.

20 lbid. 8.

21 Ibid. 4.

22 Ibid. 3.
} 


\section{Theories on the Value of Dance Video Preservation}

Besides studies that evaluate the status of dance collections in Canada, other sources debate the value of documenting and preserving dance on video. In the book Dance on Screen (2001) for example, Sherril Dodds discusses how dance on screen has been both criticized and celebrated. ${ }^{23}$ On one hand, dance-film critics such as Sacks, Bayston, Penman, Barnes and Parry do not trust the technological mediation involved in recording dance on video. They argue that the medium becomes part of the dance and the video viewing experience is not like the viewing experience of a live performance. ${ }^{24}$ These critics emphasize the 'live body' aspect of dance as integral to the art form and therefore regard two-dimensional representations of dance as an alternative art form altogether. ${ }^{25}$ On the other hand, theorists such as De Marigny argue that the term "movies", which is used to denote moving pictures, suggests that the medium is inherently compatible with the movement of live bodies. They see the value in recording dance on video as they see the moving image to be 'dance-like' as well. ${ }^{26}$

In the article, "Video-Preservation of Dance" from the Journal of Aesthetic Education (1995), authors Kenton Harris and David E.W. Fenner also discuss the pros and cons of documenting and preserving dance on video. First, they recognize that visual recording and playback has afforded audiences the ability to see dance performances that they might never have had the opportunity to see live. ${ }^{27}$ While the authors think video recordings of dance

23 Dodds, Sherril. "Dance on Screen: A Contextual Framework." In Dance on Screen: Genres and Media from Hollywood to Experimental Art, 16.

24 Ibid. 17.

25 Ibid.

26 Ibid. 16.

27 Harris, Kenton, and David E. W. Fenner. "Video-Preservation of Dance." Journal of Aesthetic Education 29, no. 1 (1995): 69-78. Accessed January 16, 2015. 69. 
performances are better than no recordings at all, they also discuss the ramifications of such videos and meditate on their "aesthetic effect" ${ }^{28}$ By "aesthetic effect" they are referring to how the camera chooses where the viewer's attention rests and how the camera alters the viewer's vantage point of the dance through a large range of camera shots and angles. ${ }^{29}$ Additionally, the authors discuss how video-preserved dance might affect the way dances are taught to future generations. ${ }^{30}$ Specifically, the authors are concerned that dance videos give teachers too much detail about how a certain dance was performed. As a result, stricter instruction guidelines for the lesson are imposed on teachers. Though this may be regarded as a good effect by some, the authors argue that the transmission of a dance from one person to another is important for its continuous evolution, an evolution that qualifies dance as a living art form. In other words, using notation systems and oral transmission to re-create dance movement allows for greater artistic interpretation. ${ }^{31}$ The authors then conclude that dance video records are valuable for historical purposes but are not necessarily beneficial to the process of re-producing dance performances. ${ }^{32}$

Both these literature sources are valuable for giving detailed descriptions of various theorists' arguments regarding the use of dance video records and their effects on preserving the dance art form. While these sources provide context for the debate on this subject, they are written beyond the context of the Dance Collection Danse videos I have chosen to digitize and

\footnotetext{
28 Harris, Kenton, and David E. W. Fenner. "Video-Preservation of Dance." 70.

29 Ibid.

30 Ibid. 69.

31 Ibid. 74.

32 Ibid. 77.
} 
discuss. Therefore, I have applied these theories to analyze the value of documenting dance on the VHS tapes from the DCD collection specifically.

\section{A Resource for Cataloguing}

In order to catalogue the VHS tape collection, I used the Canadian Integrated Dance Database Standards Manual and Collier Descriptor Thesaurus, which was written by Lawrence Adams, Amy Bowring and Clifford Collier in 2008. The manual includes a history of the CIDD and gives detailed instructions on how to complete the specified fields using Filemaker Pro software. The manual also includes DCD's Collier Descriptor Thesaurus, which allowed me to select standardized dance cataloguing terminology. 


\section{Chapter 1: Background on DanceWorks and Dance Collection Danse}

Beginning its operations in 1977, DanceWorks is a Toronto-based dance organization and the city's leading presenter of independent choreographers. ${ }^{33}$ According to Katherine Cornell, writer, teacher and historian, “...DanceWorks is an essential and valued organization, not only within the Toronto dance community where it lives, but also for the Canadian dance milieu at large." 34 Without a specific curatorial vision, dance artists Johanna Householder, Martha Lovell, Irene Grainger, Janice Hladki and Joan Phillips started DanceWorks with the first performance taking place on March 27, 1977 at the Music Gallery in Toronto. ${ }^{35}$ According to Householder, their goal was to raise the "visibility of post-modern dance practices and performance"36 by using text, voice and film along with dance to explore alternative forms of expression. ${ }^{37}$ Today, DanceWorks presents emerging and established Canadian artists as well as international artists with six Mainstage productions and several smaller CoWorks performances per season. ${ }^{38}$ Since its inception, the company has recorded all their performances on a variety of media. In 2001, 2002 and again in 2013, a deed of gift was signed by Mimi Beck, Director of DanceWorks, and the audiovisual collection, as well as other archival documentation, was given to Dance Collection Danse, Canada's largest archives and research centre for theatrical dance history. ${ }^{39}$

\footnotetext{
33 “DanceWorks - About I Background." DanceWorks.

34 Cornell, Katherine. “DanceWorks At Thirty.” Dance Collection Danse Magazine, 64 (2007):12.

35 Ibid.

36 Ibid. 7.

37 Ibid.

38 Ibid. 11.

39 Bowring, Amy. "Dance Collection Danse." Dance Chronicle 34, no. 2 (2011): 276.
} 
Their role as an archives is to collect artifacts of Canada's dance history and disseminate publications related to the history they preserve..$^{40}$

Though DCD was officially founded by Lawrence and Miriam Adams (husband and wife) in $1986,{ }^{41}$ their archival ambitions formed in 1983 when they began researching Canada's early dance history. ${ }^{42}$ With initial financial assistance from local arts patron Nick Laidlaw, the Adamses began ENCORE! ENCORE!, Canada's largest dance reconstruction project to date. ${ }^{43}$ In retrospect, Miriam states, "We just had a sense that there was all this material out there." ${ }^{44}$ As a researcher, dance teacher Sonja Barton traveled across Canada interviewing those involved in the dance scene before the Canada Council took formation in 1957. In the process of gathering information from dancers, choreographers and teachers, these dance practitioners gave her many artifacts and documents related to their early dance careers, ${ }^{45}$ which provided greater resources for a six-week reconstruction project in $1986 .{ }^{46}$ About a dozen choreographies were reconstructed from the 1940s to the early 1950s and these lost works were notated and videotaped for preservation. ${ }^{47}$ Throughout the reconstruction project, the Adamses kept all the

\footnotetext{
40 Ibid.

41 lbid.

42 Ibid.

43 Ibid. 279.

44 Smith, Kathleen M. "Saving The Past for The Future." The Dance Current, March 23, 2011. 24.

45 Bowring, Amy. "Dance Collection Danse." Dance Chronicle 34, no. 2 (2011): 280.

46 Ibid.

47 Ibid. 280-281.
} 
accumulated research materials in their house. ${ }^{48}$ Even though they had no official preservation policy in place yet, caring for this collection was one of the first steps to developing DCD. ${ }^{49}$

Based on the research conducted for ENCORE! ENCORE!, DCD produced a show titled There's Always Been Dance about Canada's early (pre-1957) dance history. ${ }^{50}$ It was performed at the Canada Pavilion at Vancouver's Expo ' 86 and after this, DCD became the main collector of materials related to Canadian dance history. ${ }^{51}$ Developing a reputation through publishing and distributing an inventory of their archival holdings, universities, performing arts schools and arts conferences started inviting DCD to conduct dance history workshops. Scholars and participants of the dance community also started requesting information from DCD on a regular basis..$^{52} \mathrm{Of}$ particular note are the requests for documentation of choreographies and other materials that would allow dancers to reconstruct performances no longer in production. University professors and high school teachers also request reconstruction videotapes and photographs to use as tools for teaching dance courses..$^{53}$

To date, DCD has thirty-nine published book titles, and seventy-four self-titled magazines. The magazine began as a newsletter about DCD research on dance history and their archival holdings and then grew to a thirty-two page magazine consisting of a wide variety of articles

\footnotetext{
48 Bowring, Amy. "Dance Collection Danse." Dance Chronicle 34, no. 2 (2011): 280.

49 Smith, Kathleen M. "Saving The Past for The Future." The Dance Current, March 23, 2011. 24.

50 “DCD Beginnings." Dance Collection Danse. Accessed February 1, 2015.

51 Ibid.

52 Ibid.

53 lbid.
} 
about Canada's dance heritage written by the field's top dance historians. ${ }^{54}$ Currently, DCD's collection is composed of:

- approximately 425,000 documents (business records, souvenir programs and house programs, photographs, posters, correspondence, postcards, promotional materials, etc. from 550 different artists, teachers and companies

- 2,000 moving image recordings on a variety of formats (VHS, 1/2 inch, 3/4 inch tape, etc.)

- 1,100 hours of oral history interviews

- 900 costumes, props, and set pieces

- 200 art works ${ }^{55}$

Most of the collection consists of materials from the 20th century and the collection reflects an emphasis on theatrical dance in Canada rather than social forms of dance. ${ }^{56}$ Materials are acquired from a variety of different sources in the dance community: dance professionals, descendants of dance professionals, artists, companies, schools, photographers and administrators. ${ }^{57}$ According to their mandate, "We $[\mathrm{DCD}]$ achieved a world-wide reputation as a pioneer in the collection, preservation and dissemination of Canadian dance legacies...We share our unique resources through public and virtual exhibits, workshops, publications and performance." 58

\footnotetext{
54 Ibid.

55 "Dance Collection Danse By the Numbers." Publicity Handout. Dance Collection Danse. 2015.

56 Bowring, Amy. “Dance Collection Danse." Dance Chronicle 34, no. 2 (2011): 285.

57 Ibid. 285.

58 "DCD Beginnings." Dance Collection Danse.
} 


\section{Chapter 2: Preservation Issues}

\section{The Science of Magnetic Tape Degradation}

An inherent difficulty to preserving VHS tape collections is the magnetic medium's high sensitivity to unsuitable storage conditions. ${ }^{59}$ According to the Canadian Conservation Institute (CCI), incorrect temperature and incorrect relative humidity are two "agents of deterioration" that are particularly detrimental to magnetic media materials. ${ }^{60}$ Specifically, high temperatures and damp environments catalyze the magnetic tape's binder deterioration through a process called hydrolysis. ${ }^{61}$ When the polymer in the tape binder is subject to hydrolysis (exposed to moisture), the longer polymer molecules become shorter as the water molecules break them apart. The organic acid by-products of the polymer breakdown then catalyze the hydrolytic process. ${ }^{62}$ As a result, the integrity of the binder is compromised and the tape becomes softer, more brittle and even "sticky" in extreme cases. Since the binder is the substance that secures the magnetic recording to the base of the tape, ${ }^{63}$ a binder that is too soft means the magnetic particles in the gelatin of the tape may also lose cohesion, resulting in image and/or audio loss. ${ }^{64}$

\footnotetext{
59 "The Preservation of Magnetic Tape Collections: A Perspective." National Endowment for the Humanities Division of Preservation and Access. December 22, 2006. 4.

60 "Agent of Deterioration: Incorrect Relative Humidity." Canadian Conservation Institute.

61 "The Preservation of Magnetic Tape Collections: A Perspective." National Endowment for the Humanities Division of Preservation and Access. December 22, 2006. 6.

62 Ibid.

63 Lindner, Jim. "Magnetic Tape Deterioration: Tidal Wave at Our Shores." January 1, 1996. Accessed January 16, 2015.

64 "The Preservation of Magnetic Tape Collections: A Perspective." National Endowment for the Humanities Division of Preservation and Access. December 22, 2006. 6.
} 
In order to avoid hydrolytic deterioration, it is best that magnetic media be stored in environments of low temperature and low relative humidity ${ }^{65}$ According to the CCI, even normal room temperatures are too high for the long-term preservation of unstable materials carrying images and sound. ${ }^{66}$ VHS tapes, which are classified as a very high-sensitivity material, are expected to last only seven years if stored in a room of $30^{\circ} \mathrm{C}$, fifteen years in a room of $25^{\circ} \mathrm{C}$ and thirty years in a room of $20^{\circ} \mathrm{C} .{ }^{67}$ By comparison, VHS tapes would be expected to last 150 years in cool storage $\left(\sim 10^{\circ} \mathrm{C}\right)$ and 600 years in cold storage $\left(0^{\circ} \mathrm{C}\right) \cdot{ }^{68}$ Keeping VHS tapes in lower temperatures helps preserve them because it slows the hydrolytic process and it keeps the tape base from expanding and distorting the tape playback. ${ }^{69}$ In order to avoid moisture induced deterioration, the $\mathrm{CCI}$ also recommends that magnetic media be kept in rooms with low relative humidity. ${ }^{70}$ For materials stored in $20^{\circ} \mathrm{C}$, tapes in $50 \%$ relative humidity last thirty years while tapes in $20 \%$ relative humidity last 150 years. ${ }^{71}$ As indicated by the CCI's research, placing VHS tapes in proper storage conditions significantly maximizes their longevity.

\footnotetext{
65 Lindner, Jim. “Magnetic Tape Deterioration: Tidal Wave at Our Shores.” January 1, 1996.

66 "Agent of Deterioration: Incorrect Temperature." Canadian Conservation Institute. Accessed April 15, 2015.

67 Ibid.

68 Ibid.

69 "Magnetic Tape and Storage and Handling: A Guide for Libraries and Archives." The Commission on Preservation and Access. June 1995. 21. Accessed April 1, 2015.

70 "Agent of Deterioration: Incorrect Relative Humidity." Canadian Conservation Institute. 71 Ibid.
} 


\section{The Funding Conundrum: Why Tape Collections are Difficult to Preserve in Practice}

Despite knowing the ideal storage conditions for VHS tapes, obtaining proper storage facilities is difficult and costly. Unfortunately, the reality is that smaller archival institutions, including Dance Collection Danse, do not have sufficient funds for cold storage facilities with humidity control. As discussed by a study of dance collections in Canada, "Archival preservation collections require extensive infrastructure and continuous care - both being costly, and specialized undertakings." 72

Why do many arts-related archives not have the resources to maintain their audio-visual collections in ideal storage conditions? Generally speaking, arts-related collections are classified as low preservation priority. Notably, in 2008 the Department of Canadian Heritage announced it would end a number of arts and culture programs or reduce their budget. ${ }^{73}$ Two programs officiated by Audio-Visual Preservation Trust of Canada, the Feature Film Preservation and Access Program and the Canadian Music Preservation and Access Program were "phased out" as of April 1st, 2009. ${ }^{74}$ Government resources are more likely to be allocated toward preserving military and political history. And, the fact that government-sponsored archives are also being neglected means that allocating funds to private sector and non-traditional records is even less likely. ${ }^{75}$ In a study on the status of dance collections in Canada, archivist Theresa Rowat concluded:

The heritage infrastructure of museums, galleries, archives and libraries that is

\footnotetext{
72 Rowat, Theresa. "Study of dance collections in Canada." 18.

73 "Part 1: Summary of Arts and Culture Budget Reallocations." Parliament of Canada. Accessed June 12, 2015.

74 Ibid.

75 "Federal Libraries, Archives Shutting down." CBC News. May 2, 2012. Accessed April 1, 2015.
} 
a vital part of the sustainability of other disciplines does not serve the dance discipline adequately for various systemic reasons. The dance legacy holdings that do exist are largely with the dance community - with individuals, with company archives, and with Dance Collection Danse. ${ }^{76}$

Throughout her study, Rowat contacted several institutions with heritage mandates and asked them how their institution helps preserve or sheds light on dance documentation and history. She found that dance was not a discipline explored by these heritage organizations and dance-related ephemera and documentation was considered low collection priority. ${ }^{77}$ Though this study was conducted in 2003, and interest in dance collections has since been generated, dance institutions and collections still struggle to find a prominent place in the heritage sector. ${ }^{78}$

Since DCD holds most of Canada's dance-related ephemera and documentation, the funding issues faced by DCD have a large impact on Canada's dance legacy. ${ }^{79}$ Though DCD receives government subsidy through the Canada Council, the Ontario Arts Council, the Toronto Arts Council and from foundations and private donors, ${ }^{80}$ the high cost of cold storage facilities deters DCD from implementing the ideal environments required to take optimal care of their audiovisual material. Despite increased emphasis on collections management, constant rehousing and following collections care standards on par with museums of the same size, lack of funds, infrastructure and human resources have inhibited temperature and relative humidity controlled facilities for the audio-visual collections from being implemented at this time. ${ }^{81}$ Despite past

\footnotetext{
76 Rowat, Theresa. "Dance Heritage Review and Current Status." May 282003.

77 Ibid.

78 Ibid.

79 Rowat, Theresa. "Study of dance collections in Canada." 17.

80 Bowring, Amy. "Dance Collection Danse." Dance Chronicle 34, no. 2 (2011): 283.

81 Amy Bowring in conversation with the author June 17th, 2015 at Dance Collection Danse.
} 
financial hurdles, however, DCD is optimistic about the future. According to Director of Collections and Research Amy Bowring, DCD is entering a transitional phase. They want to build the human and financial resources required to move their collection to a building large enough to consolidate the existing collection and provide space for new acquisitions. ${ }^{82}$ Bowring writes, "Future plans include a facility that can accommodate their collections management, administrative offices, exhibitions, lectures, film screenings, and studio space for restructuring/ remounting works and providing preservation services for new works such as notation and digital video recording." ${ }^{.83}$

In her study, Rowat argues that dance archives (in general) rely too heavily on the arts sector for funding. As a result, they do not have the resources to build preservation facilities or hire enough staff to properly handle and catalogue the collections. She suggests that the responsibility of dance collections should be shared by arts, heritage and education sectors in order to be adequately accounted for by their institutions ${ }^{84}$ However, Bowring argues that DCD is actually better off being funded by the arts community, stating that arts funding is more plentiful and more secure than heritage funding currently. ${ }^{85}$

\section{Solutions to the Preservation Problem - How to go about Long-Term Storage?}

Since smaller institutions such as Dance Collection Danse cannot afford professional storage facilities, migrating data is the only available preservation strategy for their audio-visual

\footnotetext{
82 Bowring, Amy. "Dance Collection Danse." Dance Chronicle 34, no. 2 (2011): 289.

83 Ibid.

84 Rowat, Theresa. "Dance Heritage Review and Current Status."

${ }^{85}$ Amy Bowring in conversation with the author June 17th, 2015 at Dance Collection Danse.
} 
collections. For DCD, it has been decided that the digitized VHS tapes as well as other digitized formats will be transferred to LTO tapes (Linear Tape Open), which is an open-format, tapebased storage technology that stores files as opposed to analog datas. ${ }^{86}$

DCD's plan is to fill a two-terabyte drive of digital information and then transfer to LTO.$^{87}$ When they are ready to transfer, they will use the latest LTO technology available. Currently in its sixth generation ${ }^{88}$, LTO tapes can hold up to $6.25 \mathrm{~TB}$ of compressed storage per cassette and 2.5 TB of non-compressed storage. ${ }^{89}$ LTO tapes are designed to last thirty years, if kept in moderate storage conditions..$^{90}$

The benefits of using LTO as a long-term preservation strategy are:

- LTO is an "open" format which means different companies produce LTO drives and cartridges that are compatible with each other.

- LTO has a better bit error rate than disk.

- LTO tapes cost approximately $\$ 100.00$ CAD per tape, which is less expensive than a disc with similar space capacities.

- Tapes are less fragile than hard drive so they can be transported in a faster, more cost efficient manner.

- LTO tapes can be stored offline so they are not vulnerable to viruses or software issues like other online storage. ${ }^{91}$

In addition to putting their digital files on LTO, DCD has decided to keep the VHS tapes in their storage facility. This is a precaution DCD is taking in case the LTO tapes are compromised or the digital files corrupt. ${ }^{92}$

\footnotetext{
86 "Facts About LTO and LTFs." Storage DNA. 2012. Accessed April 1st, 2015.

${ }^{87}$ Amy Bowring in conversation with the author June 17th, 2015 at Dance Collection Danse.

88 "FAQ." Ultrium LTO. Accessed April 1, 2015.

89 "Benefits." Ultrium LTO. Accessed April 1, 2015.

90 "Facts About LTO and LTFs." Storage DNA. 2012.

91 "Benefits." Ultrium LTO.

92 Amy Bowring in conversation with the author June 17th, 2015 at Dance Collection Danse.
} 


\section{Chapter 3: Debating the Value of Preserving Dance on Video}

Since videos started being used to document dance performances, scholars have debated the archival value of a dance video record (not the value of producing dance music videos or movies about dance). An archivist will preserve a film because the film is the contents' medium of origin; it is the document. Live performances on video, however, are not in their medium of origin (the original medium is intangible). The video is a record of a performance that took place but it is not the actual performance. Questions around the nature of the record then arise: is this an "authentic" record of the performance? Does the video reconstruct the experience of the live performance? How does the camera mediate the performance and to what effect? Are dance videos an effective tool for preserving dance? Is a dance video an appropriate tool for teaching this particular art form?

As discussed in the literature review, theorists have outlined the advantages and disadvantages of documenting dance on video. Regarding questions of authenticity, scholars Kenton Harris and David Fenner argue that the viewing experience of a live performance is much different than watching a video of a live performance..$^{93}$ Their main point of contention is that live performance audience members have agency of focus. In other words, an audience member can choose to pay attention to one dancer over another or they can look at the stage from a holistic perspective. With video, the focus of the performance is decided by the camera person and where they choose to place the camera in relation to the stage.${ }^{94}$ Additionally, the camera work might interfere with the spectator's attention. With pans and zooms (movements that cannot be made with the human

\footnotetext{
${ }^{93}$ Harris, Kenton, and David E. W. Fenner. "Video-Preservation of Dance." 70. 94 Ibid.
} 
eye), the spectator might focus on actions of the camera as opposed to the action on the stage. ${ }^{95}$ In the words of Kenton and Harris, the videographer becomes in charge of the "aesthetic effect" which could conflict with the original aesthetic intentions of the choreographers. ${ }^{96}$ For example, a choreographer might organize their dance in such a way that they do not want to create a single focal field - the formations are created such that the desired aesthetic of the performance can only be appreciated as a whole. If a videographer were to "interfere" with zooms, and focus on one or two dancers, the intention of the choreographer would be thwarted and the vision for the performance compromised.${ }^{97}$ This leads to questions of authorship: when looking at a dance video, who is its main creator? Is it the choreographer who brought the dance before the camera or is it the videographer who brought the dance to the screen? What is the document actually documenting? Notably, in the dance community, videographers are hired to record/document the performance only and there is no legal question that the copyright of the dance lies with the choreographer. ${ }^{98}$ Technicalities aside, a high degree of camera interference can problematize the distinction between a video record that mostly documents the choreography and a video record that mostly documents the camera person's filmic accentuation of the choreography.

Other scholars also argue that dance video records fail to capture the "true" dance experience.${ }^{99}$ In their opinion, the "true" dance experience can only be obtained by watching the live performance. In the words of a critic who goes by JN (1995), "Dance...is a live thing, and

\footnotetext{
95 Harris, Kenton, and David E. W. Fenner. "Video-Preservation of Dance." 70.

96 Ibid.

97 Ibid.

${ }^{98}$ Amy Bowring in conversation with the author June 17th, 2015 at Dance Collection Danse.

99 Harris, Kenton, and David E. W. Fenner. "Video-Preservation of Dance." 72.
} 
quite how it fits on TV is a moot point". ${ }^{100}$ To this end, there is no authentic way of documenting the experience of the performance, perhaps just some of its mechanics. As stated by Dodds, "Dance is characterized by its use of space, time and energy in relation to movement and it is these three phenomena that can be most distorted through the television medium." 101 She then explains how the eye perceives the aliveness and three dimensionality of the real dance as opposed to the camera, which is limited by the flatness of the screen. ${ }^{102}$

Another topic of discussion is how dance video will affect the way dance is taught to future generations. On one hand, video records mean the preservation of dance is not solely entrusted to the memories of dancers and choreographers. ${ }^{103}$ While notational systems for dance do exist, they are costly, scarcely used and not accessible to everyone. Dance videos do, however, faithfully record the mechanics of choreography as interpreted by the dancers and can keep the interpretation of the choreography alive in a detailed fashion. ${ }^{104}$ In this regard, dance videos are an effective tool for documentation, no matter how "flat" and inauthentic it can be. On the other hand, dance is traditionally transmitted through person-to-person communication: choreographer to dancer, teacher to dancer, or dancer to dancer. Within the transmission process, the dances naturally shift and evolve in unintentional and intentional ways. For example, one dancer might be trained to execute a jump in a different way than was originally choreographed (unintentional) and one choreographer might choose to alter the formation of a certain movement in order to suit

\footnotetext{
100 qtd. JN in Dodds, Sherril. "Dance on Screen: A Contextual Framework" in Dance on Screen: Genres and Media from Hollywood to Experimental Art. 17.

$101 \mathrm{lbid} .30$.

102 Ibid. 31.

103 Harris, Kenton, and David E. W. Fenner. "Video-Preservation of Dance." 75.

104 Ibid. 72.
} 
the performance venue (intentional). ${ }^{105}$ While video documentation of a dance could lead to more rigid reconstructions of a particular dance, it is arguable that the person-to-person evolution of dance is part of the living nature of the art form. ${ }^{106}$ In other words, the literal preservation of dance is authentic to the live, interactive quality of performance art. For example, one would expect The Nutcracker to be presented differently by different companies and different dancers at different times. No one dance performance can be repeated exactly, nor is that necessarily the goal.

To be sure, Kenton and Harris do not argue that dance videos will "squelch the evolution of dance" 107 . After exercising their thoughts about the possible consequences of documenting dance on video they conclude, "Given the inevitable evolution of dance, it becomes clear that videopreservation of dance is more of a historic interest than of value for identifying two performances as those of a single dance." 108 Even with video documentation, dance will evolve in the learning and reconstruction process. Video does not threaten the alive and interactive nature of learning a dance.

Undoubtedly, recording dance on video has its advantages. For one, dance videos provide access to dances that otherwise might not be seen by all possible audiences. ${ }^{109}$ Easy to disseminate, digital dance videos can also inspire interest in dance. As stated by Jacob Zimmer, artistic director of his own company Small Wooden Shoe, "If performance is about presence and

\footnotetext{
105 Harris, Kenton, and David E. W. Fenner. "Video-Preservation of Dance." 73.

106 Ibid.

107 Ibid. 74.

108 Ibid.

$109 \mathrm{lbid} .69$
} 
liveness, digital sharing is only going to be a marker, an arrow towards an event. The more arrows, and the more people pointing towards those arrows, the more likely it is someone will find the event. ${ }^{110}$ Digital dance videos also allow institutions to create a digital archive of their past performances. ${ }^{111}$ Readily available videos from the past might generate interest in present performances and some scholars argue that online dance will help develop a new generation of dance enthusiasts. ${ }^{112}$

\section{The Value of Preserving Dance on Video for DanceWorks Specifically}

Despite the limitations of preserving dance on video, I argue that DanceWorks' VHS tapes and digital videos are of high archival value. Though it is not possible to capture "the experience" on video, DanceWorks' videos are recorded with little interference by the camera. In all the tapes, there is one camera set-up at the back middle of the venue as the camera passively records what is happening on stage. From tape to tape, some cameras are farther away than others (see Figure 4.1 and 4.2) but rarely does the camera operator pursue a close-up zoom on any of the dancers. While sometimes the camera pans to follow the dancers, to make sure they are in the centre of the screen, all the shots adopt a holistic perspective while being close enough to distinguish details of the action. In this way, the camera acts much like a spectator sitting in the back row. As noted by Harris and Kenton, this passive type of recording can, for the most part, mitigate the negative effects of camera mediation in the performance recordings. ${ }^{113}$ The caveats to this, however, are that no one's eyes are as stationary as a camera and one would

\footnotetext{
110 Williams, Anne-Marie. "Dance in the Digital Age." The Dance Current, September 30, 2008. 36. 111 lbid.

112 Ibid.

113 Harris, Kenton, and David E. W. Fenner. "Video-Preservation of Dance." 71.
} 
require a large screen in order to choose how they focus on the dance (either holistically or on specific dancers). ${ }^{114}$

In addition to the passive role of the camera in the DanceWorks tapes, the videos document historical aspects of the performances that exist outside the dances themselves. For example, the tapes document the way dancers appeared at a certain age, the way performance venues looked in Toronto at a certain time and the history of DanceWorks - what types of dances they presented and the people involved. With these videos, DanceWorks not only preserved the choreography, they recorded the history of their company's happenings, costume trends and the way the venues grew around that activity - these videos are valuable archival documents.

Digitizing DCD's VHS tapes also allows DanceWorks to share their organization's history more readily than they were ever able to in the past. Additionally, dancers and choreographers can collect clips of their performances and build video portfolios that exhibit their body of work. This will allow them to share their techniques with other dancers and choreographers. Since the field of dance research is also growing ${ }^{115}$, these videos can help serve those research needs (they can help situate dance in a social, political and economic context, shed light on areas of the city where dance performances have occurred, and provide a visual record of choreographic and design trends). Even though video records of dance have limitations with regards to the authenticity of the work, they have long-term value as a historic record of intangible cultural heritage.

\footnotetext{
114 Harris, Kenton, and David E. W. Fenner. "Video-Preservation of Dance." 71. 115 Rosa, Maria De, Marilyn Burgess, and Philip Szporer. "Canada Dance Mapping Study: Literature Review." Canada Council for the Arts. 2012. Accessed June 18, 2015.
} 


\section{Chapter 4: Cataloguing the VHS tapes using CIDD}

In order to make the contents of the VHS tapes accessible to researchers, they have been catalogued using the Canadian Integrated Dance Database (CIDD). For the purpose of this thesis, I have catalogued twenty of the VHS tapes in DCD's DanceWorks collection. The selection of VHS tapes to catalogue was made at random and by convenience.

The CIDD is a nationally distributed database that allows, not only DCD, but other dance companies and artists to organize, catalogue and preserve the various items in their collections. ${ }^{116}$ In order to expand available information about Canada's dance history, ${ }^{117}$ in 2016 CIDD software will allow users to upload records to a master database hosted by the DCD web site. ${ }^{118}$ Here, dance research catalogue records can be accessed from all over the world. ${ }^{119}$ Filemaker is the base software of the database and it is available in French and English. It is also compatible with both Mac and Windows operating systems. ${ }^{120}$

The database was developed to catalogue any items that might be part of a dance collection: photographs, videotapes, props, costumes, programs, posters, business records, etc. ${ }^{121}$ In conjunction with the database, a Collier Descriptor Thesaurus was developed in order to

\footnotetext{
116 “Canadian Integrated Dance Database.” Dance Collection Danse. Accessed April 1, 2015.

117 Esling, Natalia. "Dance Archives in an Online Environment: The Impact of Digital Media on the Preservation of Dance History." Canadian Theatre Review 156: 31.

118 Adams, Lawrence, Amy Bowring, and Clifford Collier. Canadian Integrated Dance Database Standards Manual and Collier Descriptor Thesaurus, 2008. 5.

119 "Canadian Integrated Dance Database." Dance Collection Danse.

120 Adams, Lawrence, Amy Bowring, and Clifford Collier. Canadian Integrated Dance Database Standards Manual and Collier Descriptor Thesaurus, 2008. 3.

121 Ibid. 5.
} 
standardize the dance-related terms used for data entry. It includes 200 controlled language terms that improve the search-ability of each record for users of the database. ${ }^{122}$

The prescribed fields used in the CIDD are: Main title, accession number, item designation, Collier descriptor, creators, extent/quality, physical description, dimensions, condition, materials, video format, related choreographic work, geographic locations, venues, date range, summary note, language, added subject names, related entry, restrictions, storage location, holdings, donor name, donor city, provenance, history/biography, media and media descriptor. Also, the separate table for Repertoire and all its fields allows DCD to record data related to intangible cultural heritage. The fields include: title, choreographer, choreographer nationality, premiere city, premiere date, premiere cast, length min, length sec, category, composer, music, narrator, recording, orchestra/musician, costume designer, costume builder, set designer, set builder, lighting designer, other service, other service name, program notes, notes. The following appendix includes screen shots of the twenty VHS records made in the CIDD database.

\footnotetext{
122 Adams, Lawrence, Amy Bowring, and Clifford Collier. Canadian Integrated Dance Database Standards Manual and Collier Descriptor Thesaurus, 2008. 5.
} 


\section{Conclusion:}

After digitizing a portion of DCD's VHS collection, the institution has made progress in their goals to digitize audio-visual materials for preservation. The digital files have been saved on a hard drive and copies have been given to DanceWorks. Full-length digital files may be accessed by request from DCD. With all the VHS catalogued, information about sixteen of the recorded productions are available to researchers worldwide through the CIDD, which will be available to access through the DCD web site in the near future (fall 2016). Optimistic about their future in preservation productivity, DCD hopes to digitize the rest of their audiovisual material in a time and resource efficient manner. In the words of Amy Bowring, "DCD is thinking big and long term to develop a vision for the future that will safeguard, disseminate, celebrate, and advocate for Canada's rich dance legacy." 123 With an active digitization program in place ${ }^{124}$, DCD will continue to focus on digitizing their audio-visual materials as well as cataloguing these materials for access.

123 Bowring, Amy. "Dance Collection Danse." Dance Chronicle 34, no. 2 (2011): 289.

124 Ibid. 284. 


\section{Appendix}

*Please note that details about the dancers and productions captured by these images are yet to be determined.

Figure 1: Reproduction of a still from the VHS tape labelled 5.1 DW 38

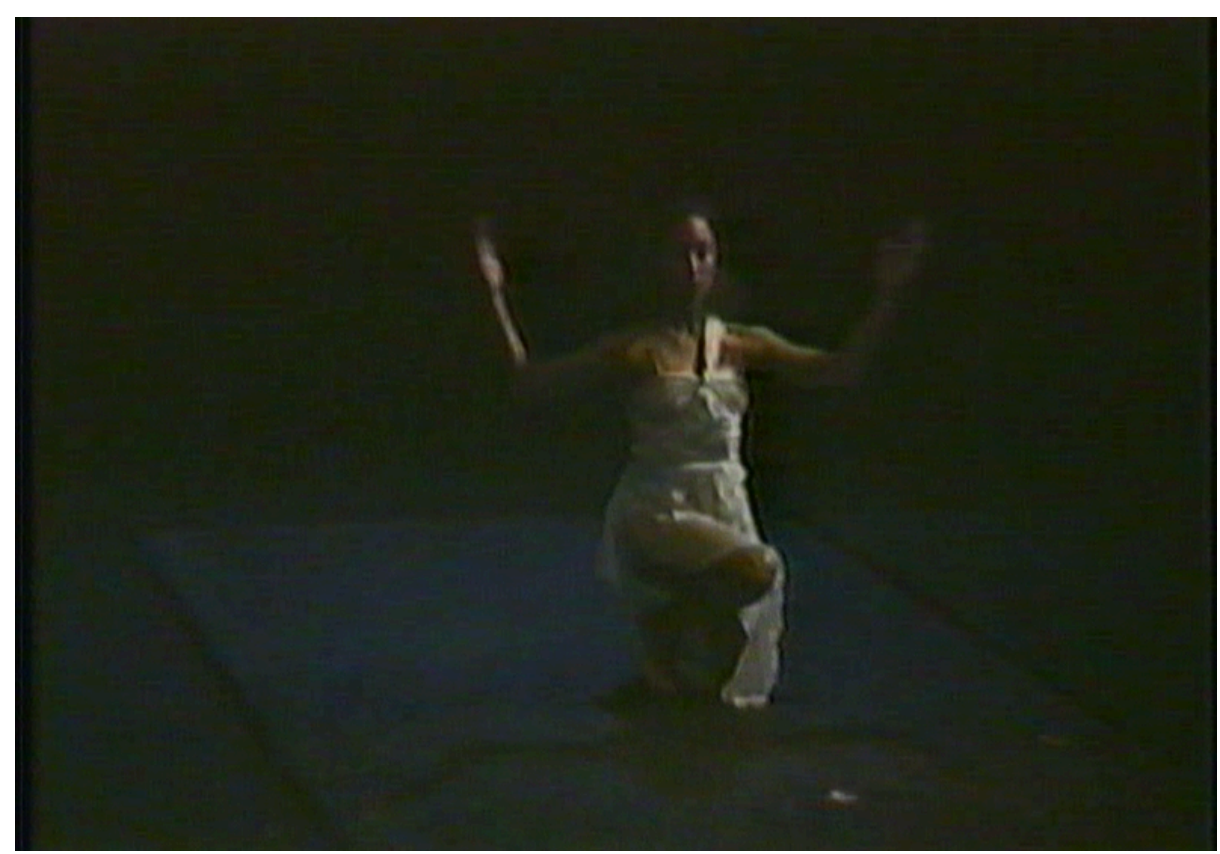

Here, the videographer panned the camera in order to place the dancer in the middle of the screen. 
Figure 2: Reproduction of a still from the VHS tape labelled 10.1 DW 43

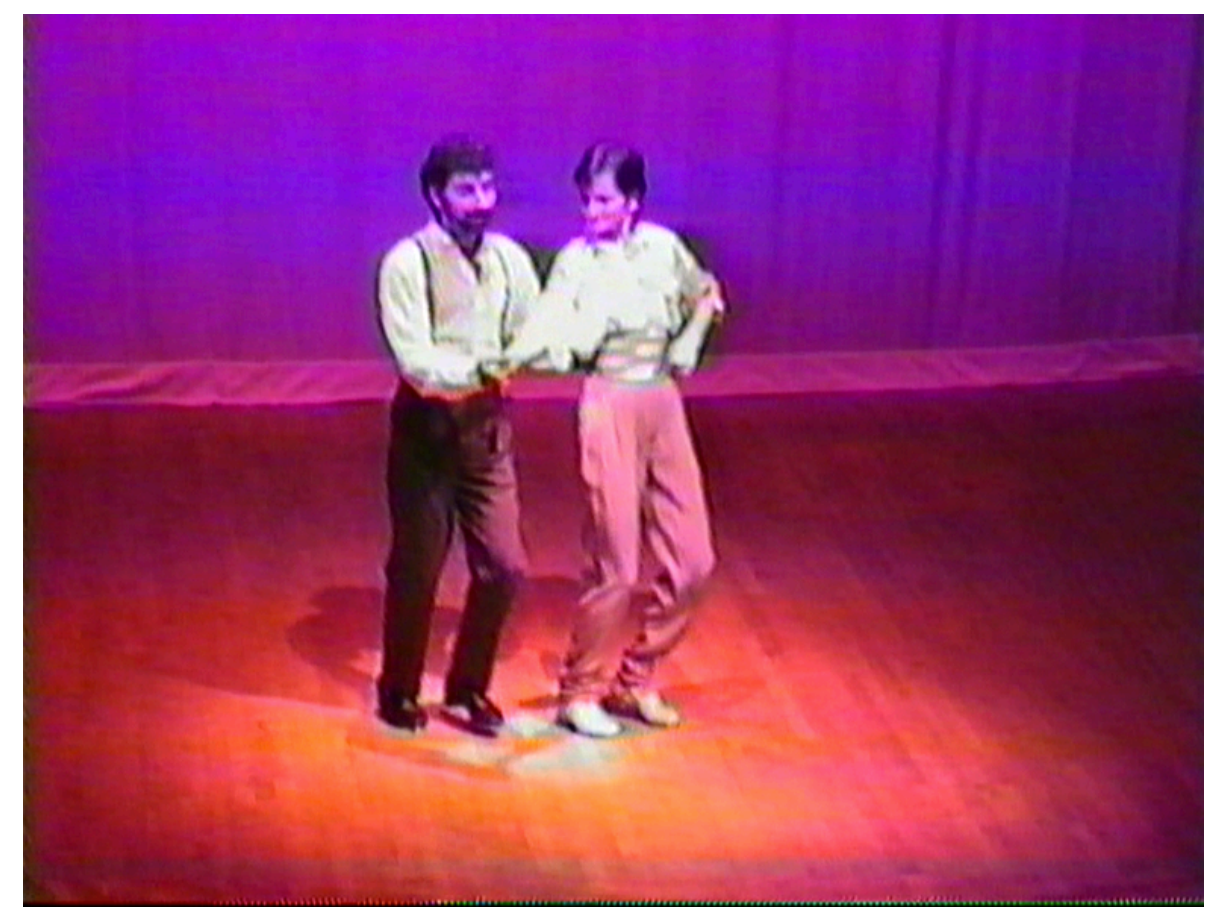

Notice the blue strip that runs horizontally across the top of the image. 
Figure 3: Reproduction of a still from the VHS tape labelled 18.3 DW 54

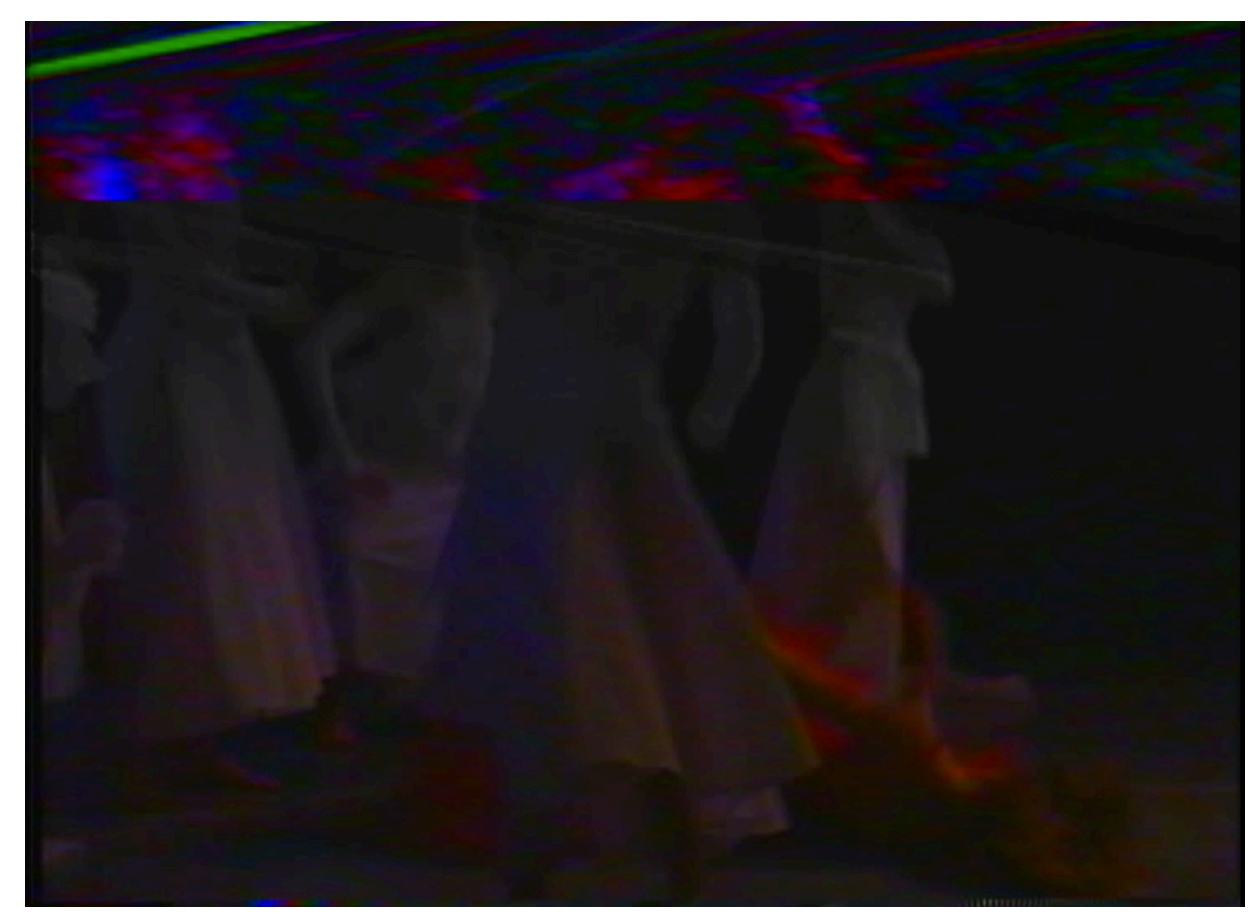

At some points the image blacks out, although it usually only lasts for a couple of seconds. 
Figure 4.1: Reproduction of a still from the VHS tape labelled 1.1 DW 25

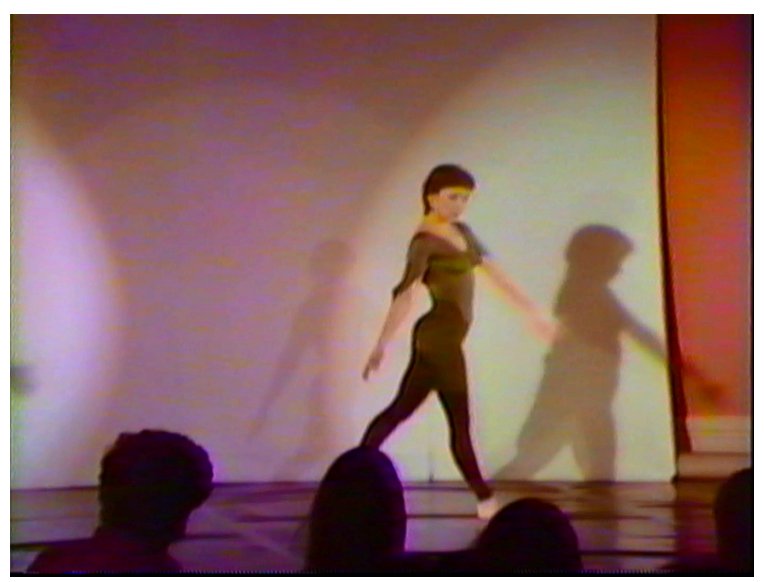

Figure 4.2: Reproduction of a still from the VHS tape labelled 27.10 DW 63

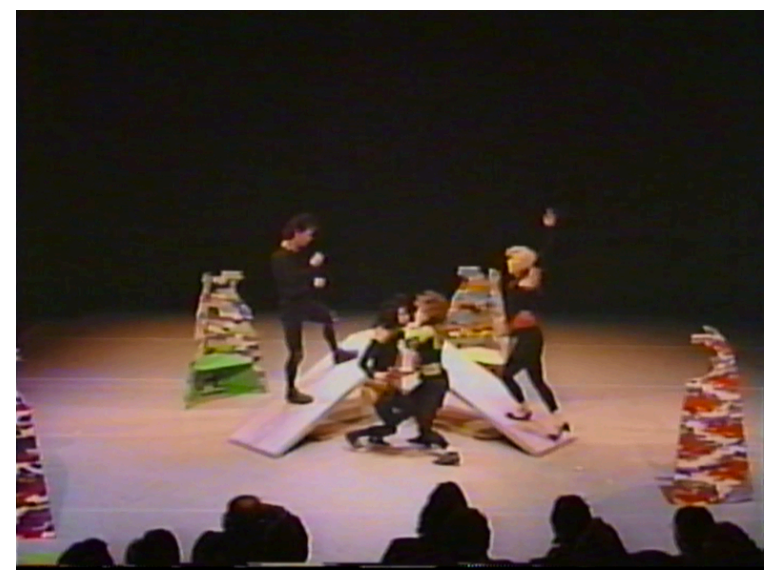

Notice the camera in Figure 4.2 is further away (or at least isn't as zoomed in) as the camera in Figure 4.1. 
Part 2: Catalogue

\section{Record 1}

*Please note that the records displayed in this catalogue do not have all their details visible. Only by clicking on the field can an observer see all the text in their boxes. These records, however, will be made accessible through DCD's web site in the Fall of 2016.

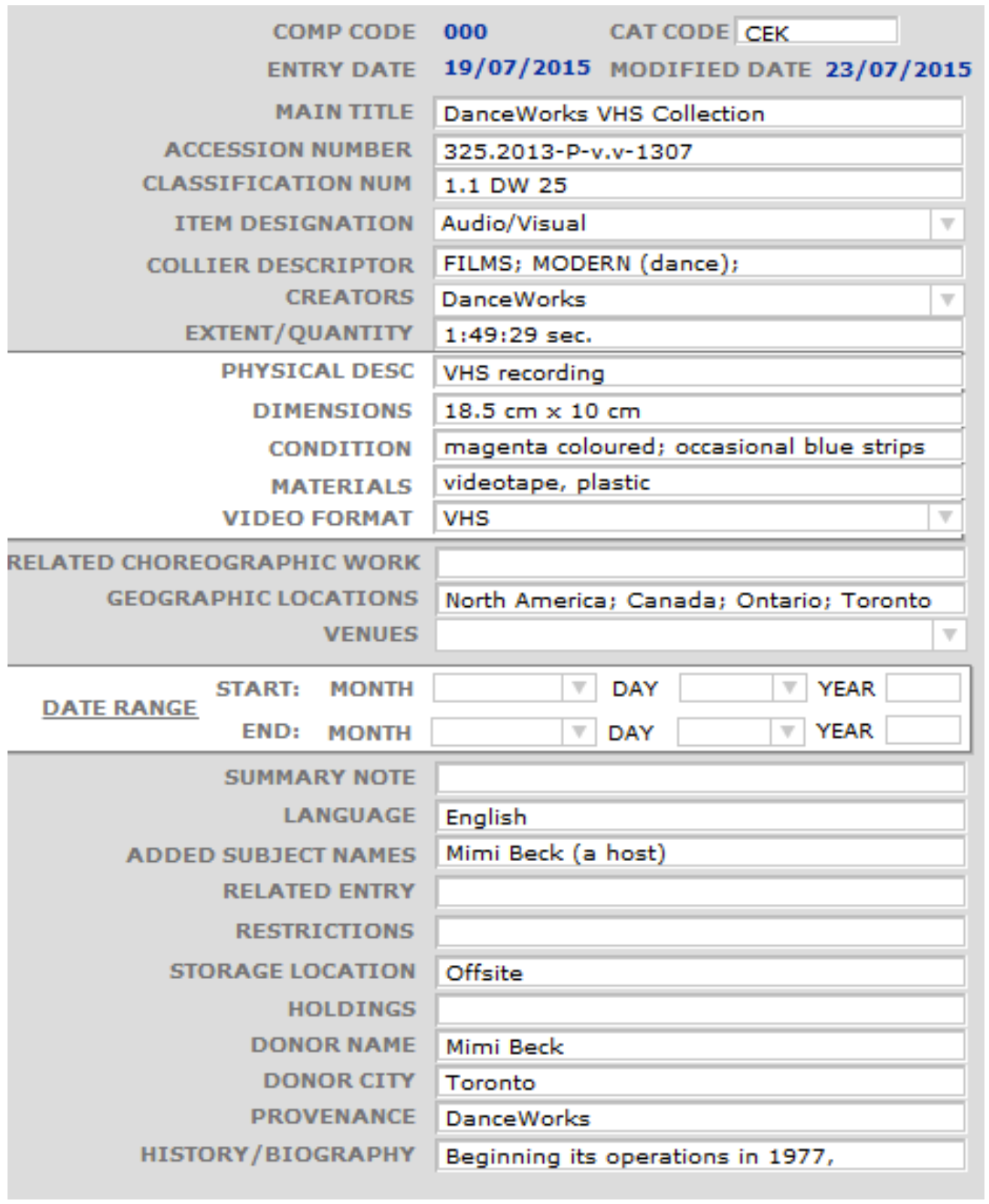




\section{Record 2}

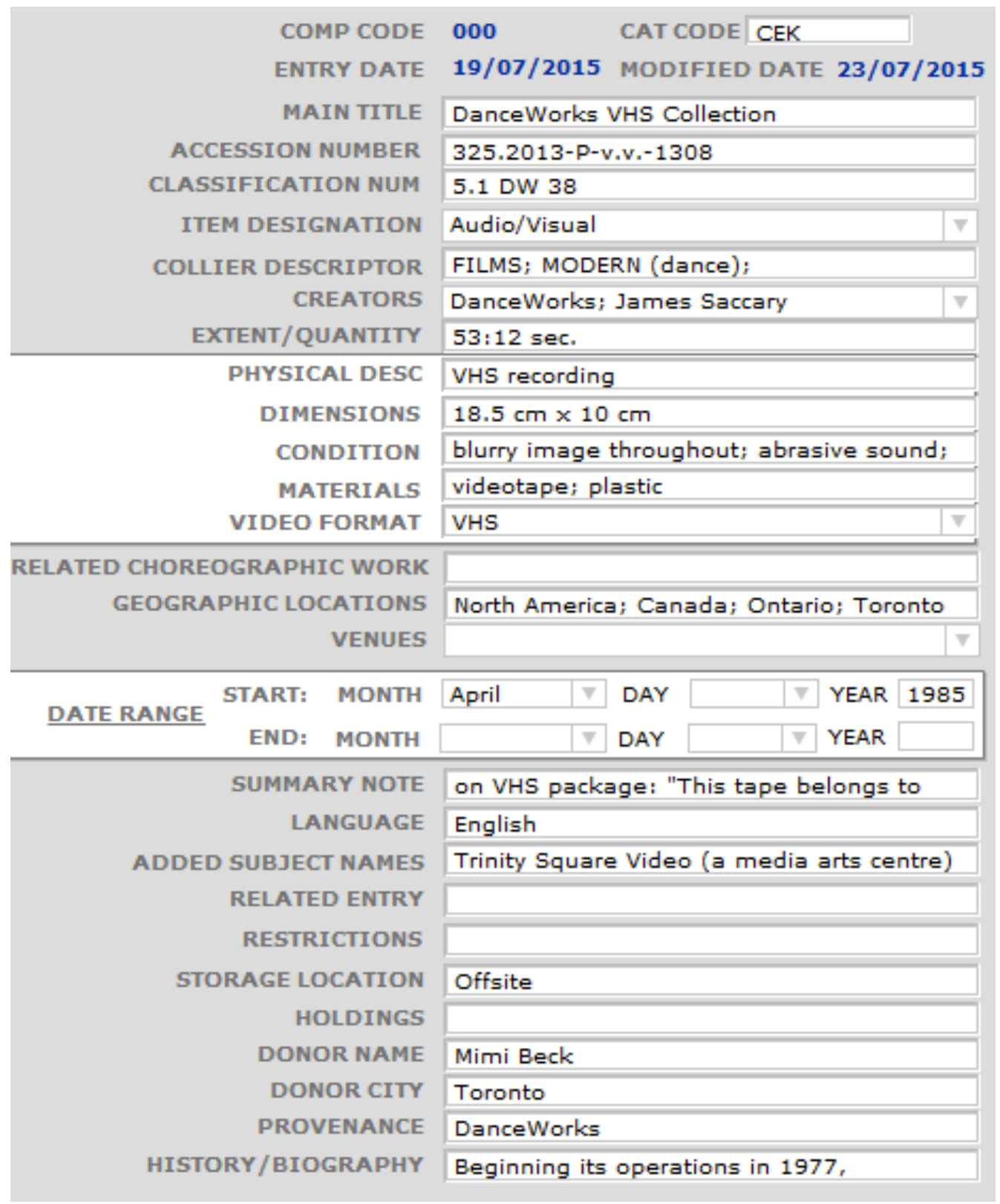




\section{Record 3}

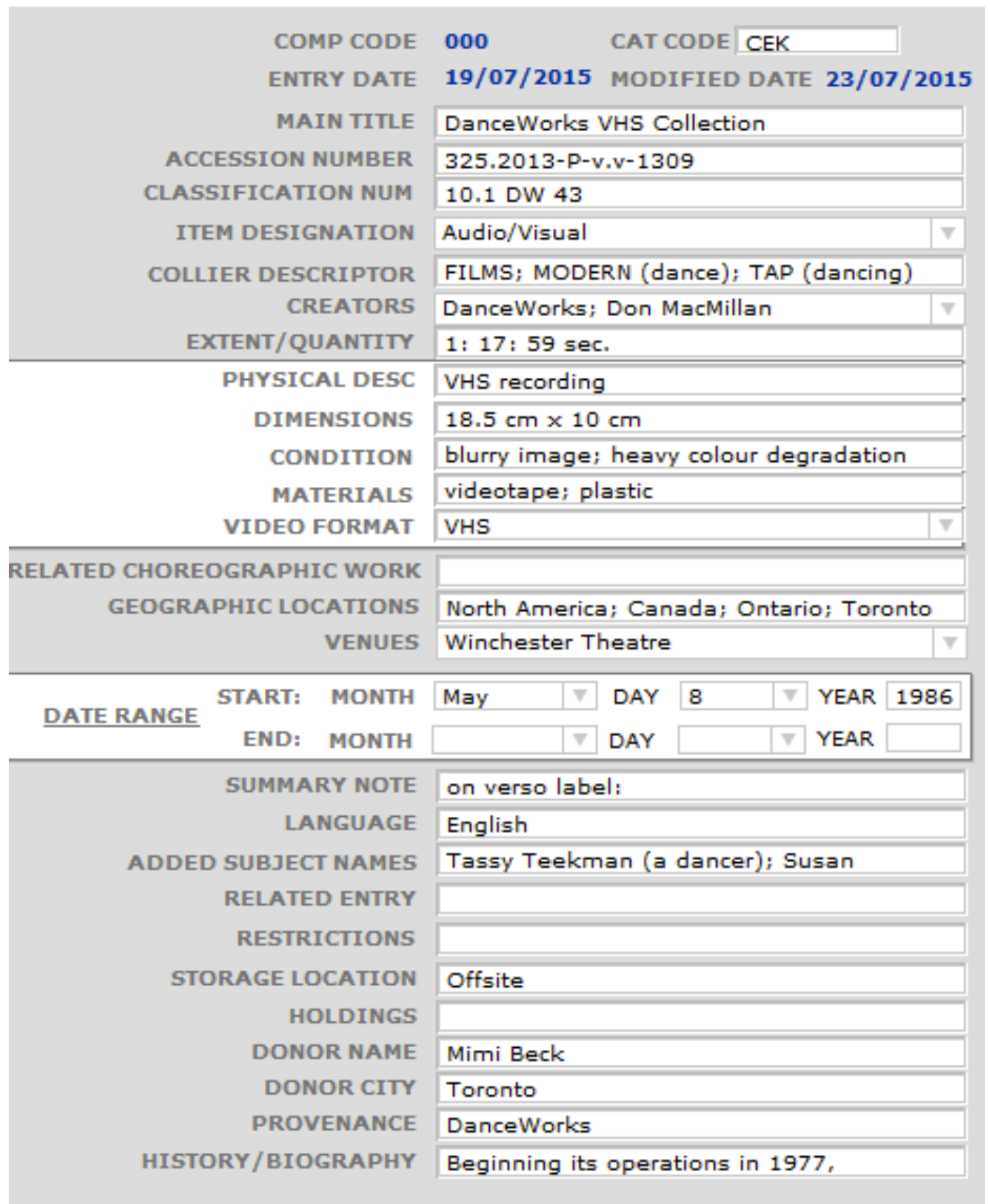




\section{Record 4}

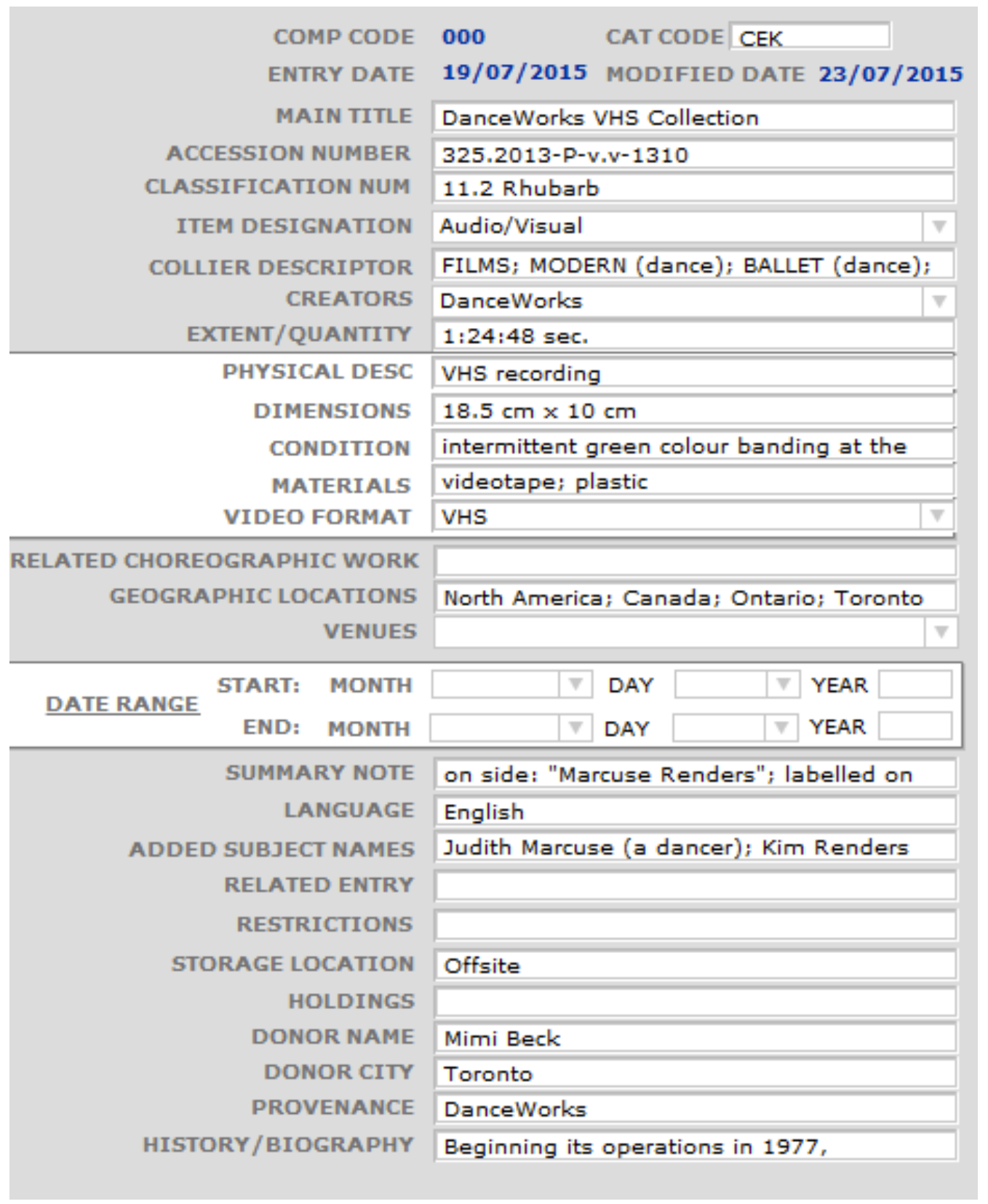




\section{Record 5}

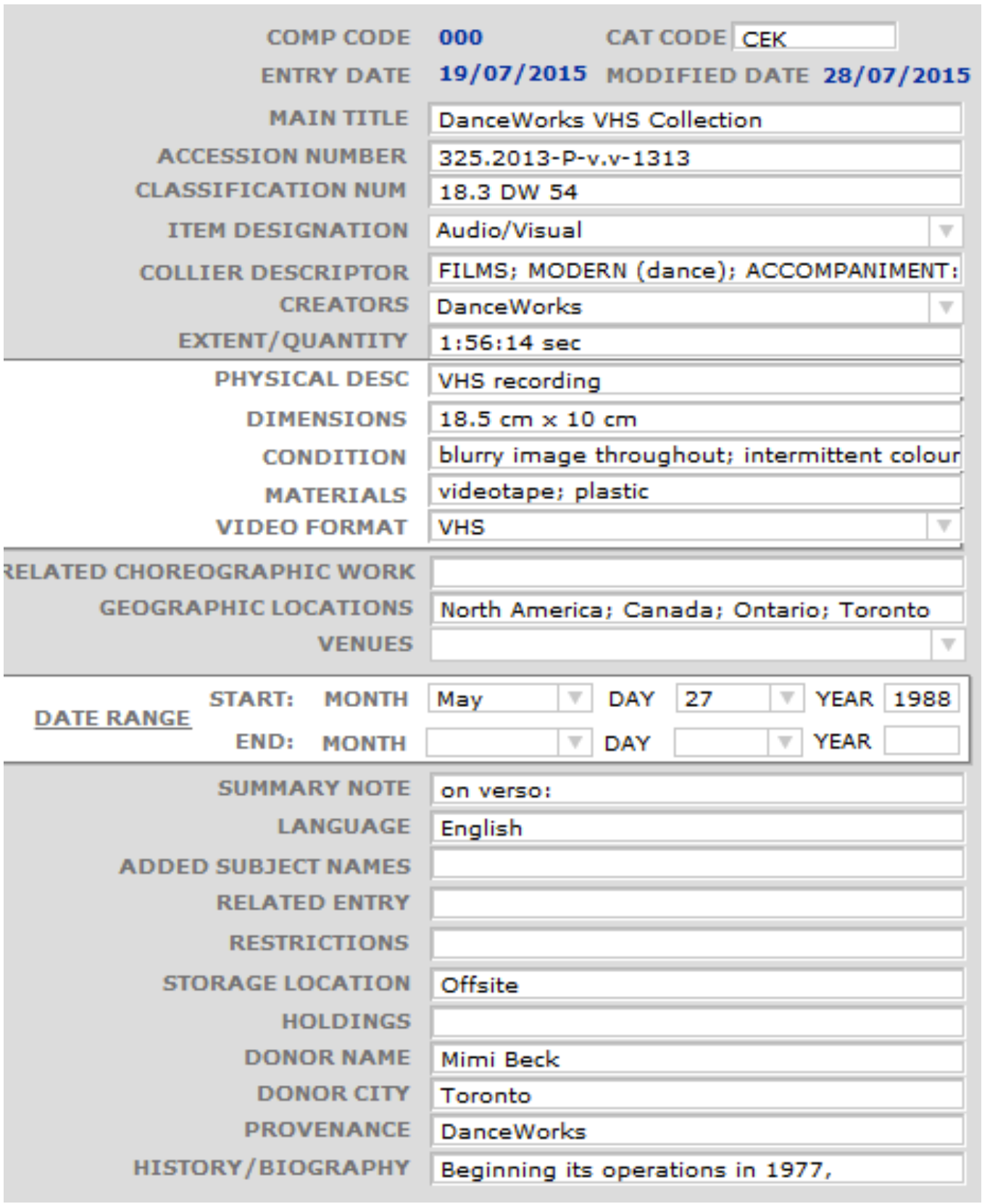




\section{Record 6}

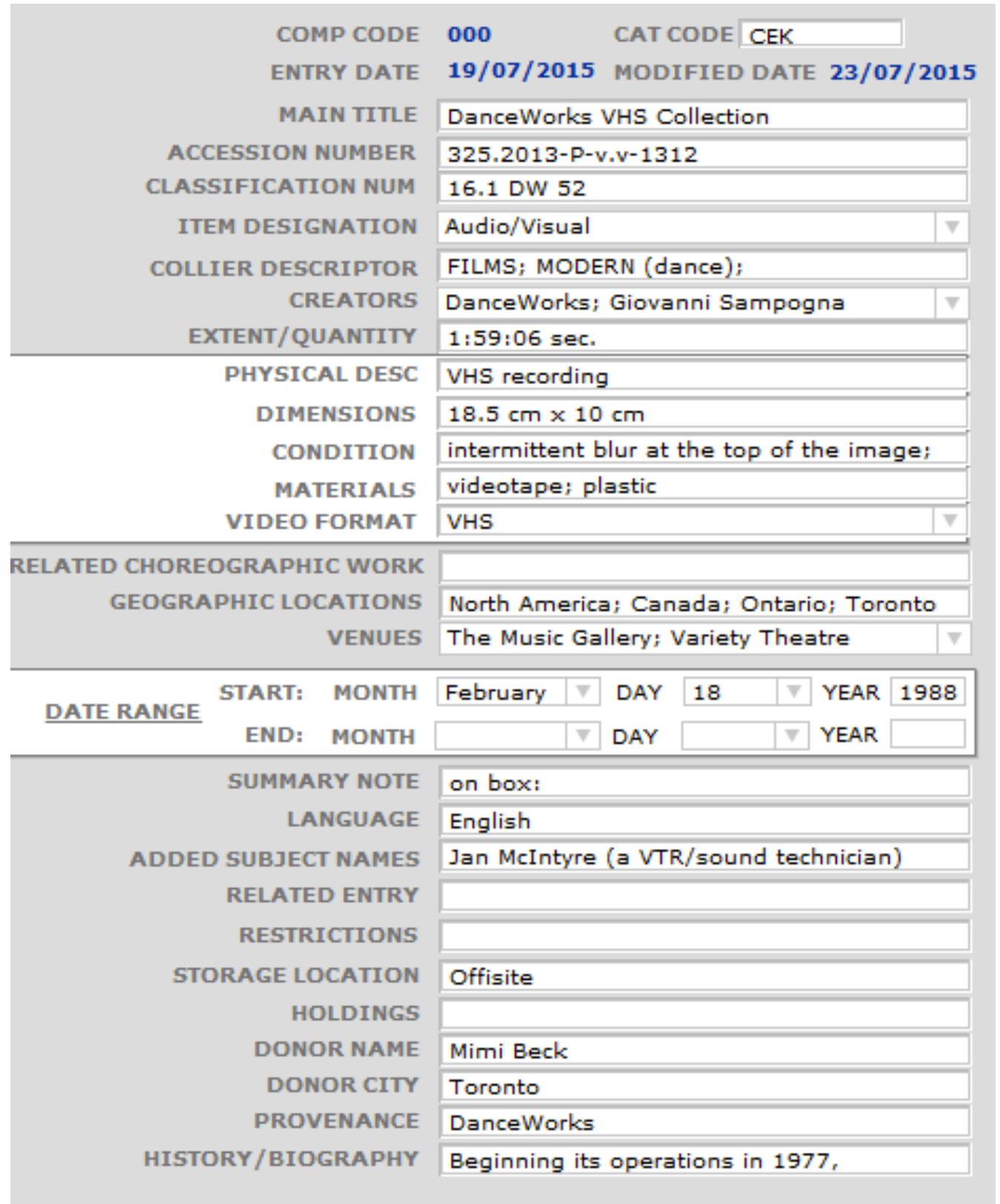




\section{Record 7}

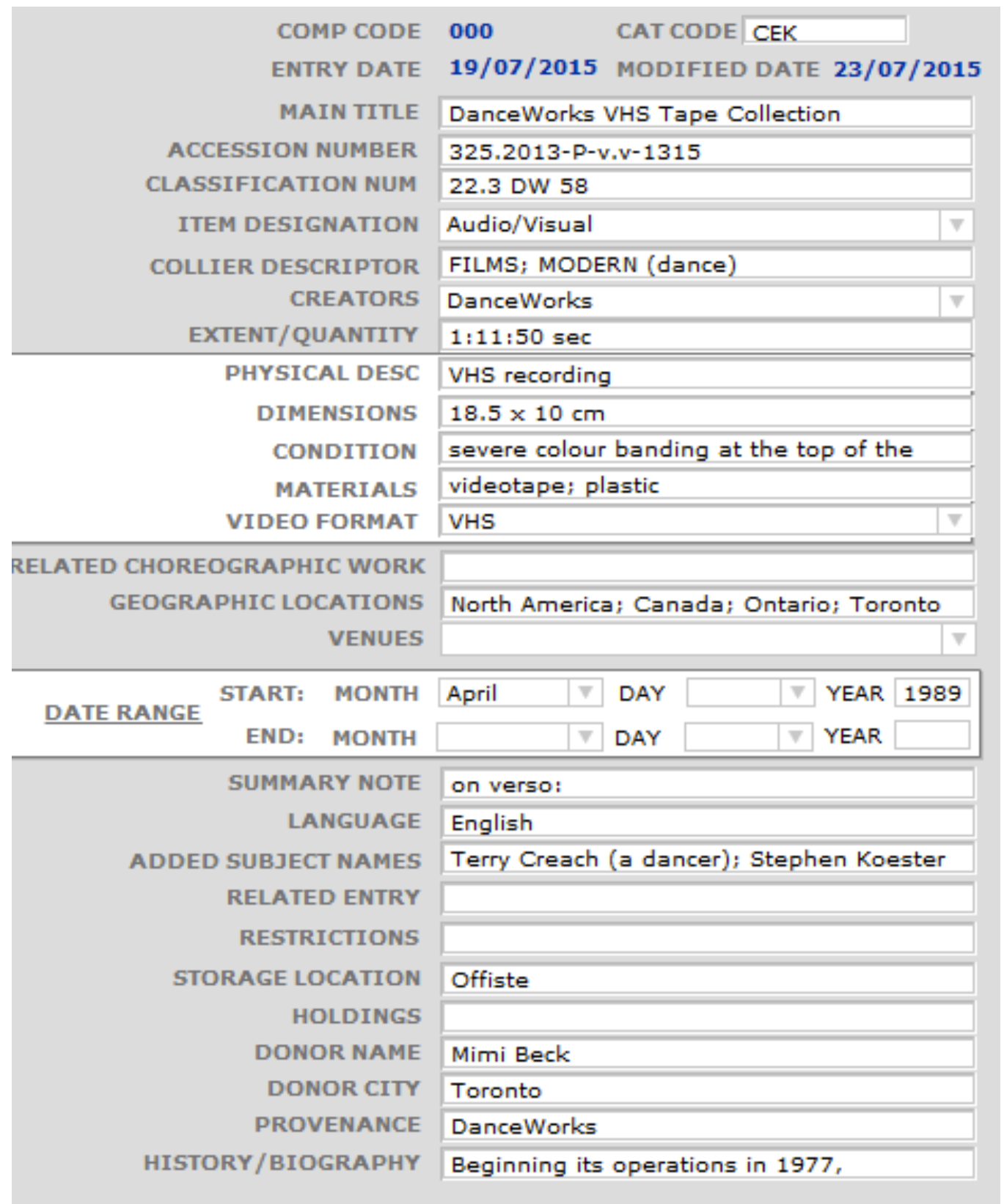




\section{Record 8}

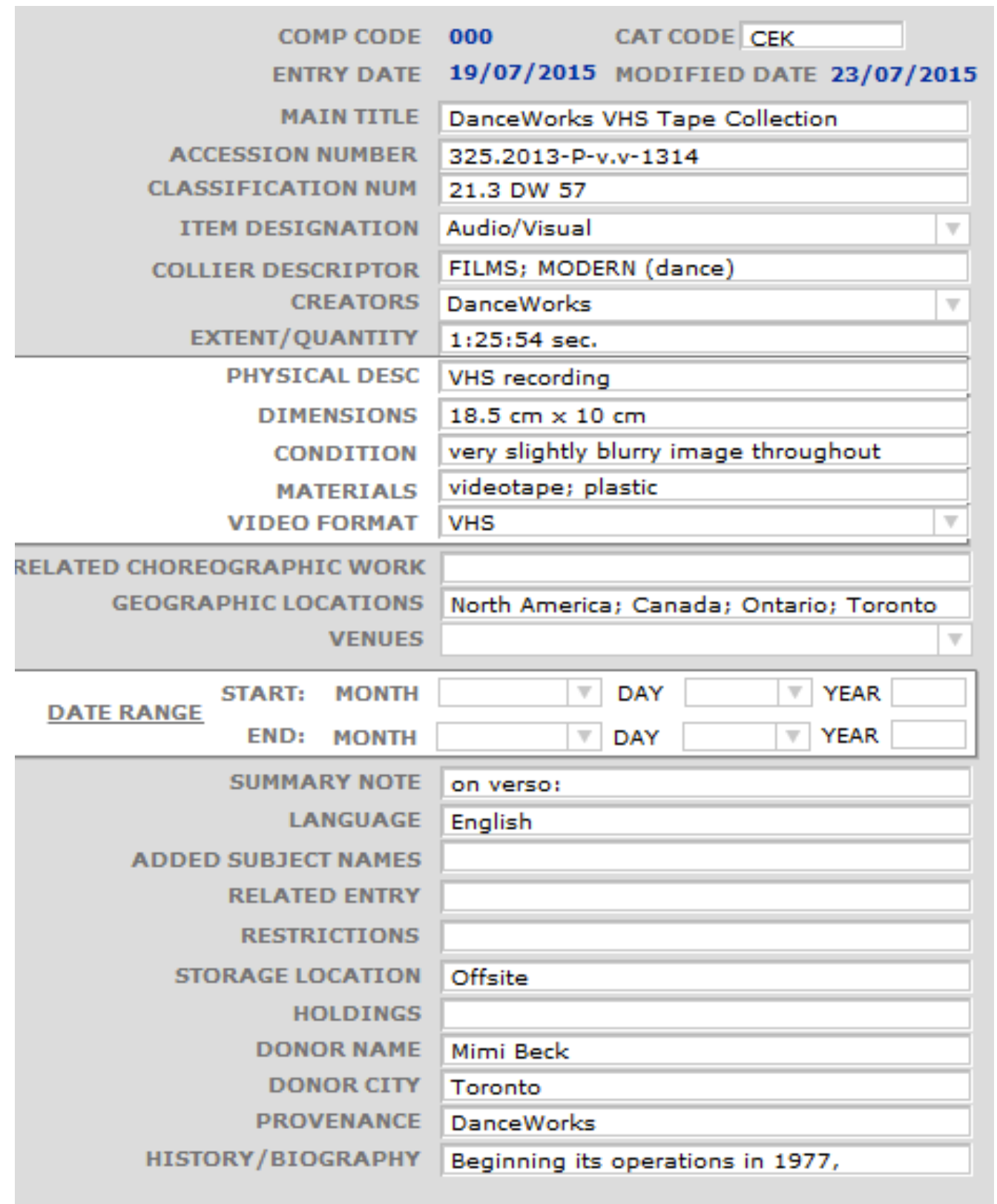




\section{Record 9}

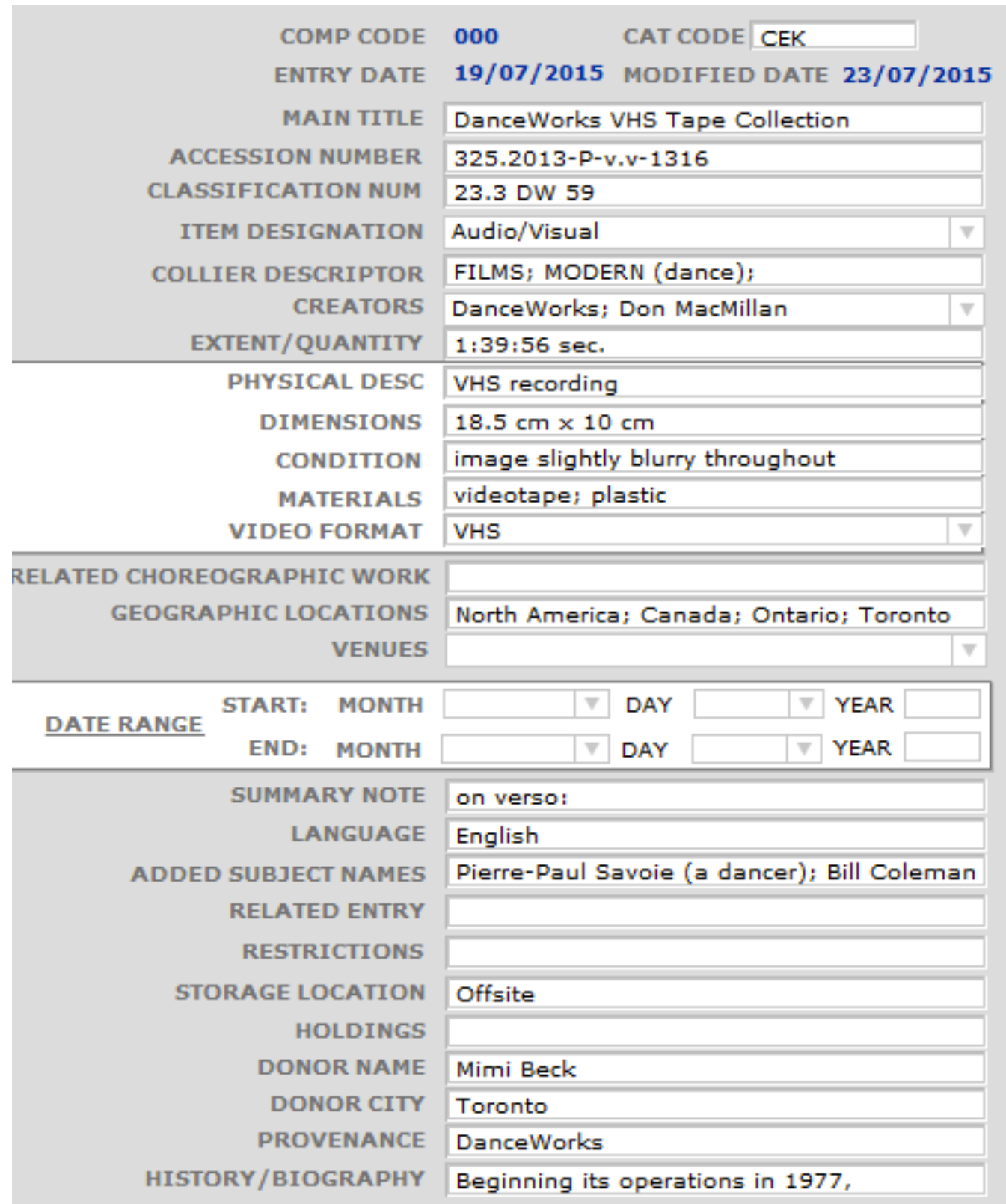




\section{Record 10}

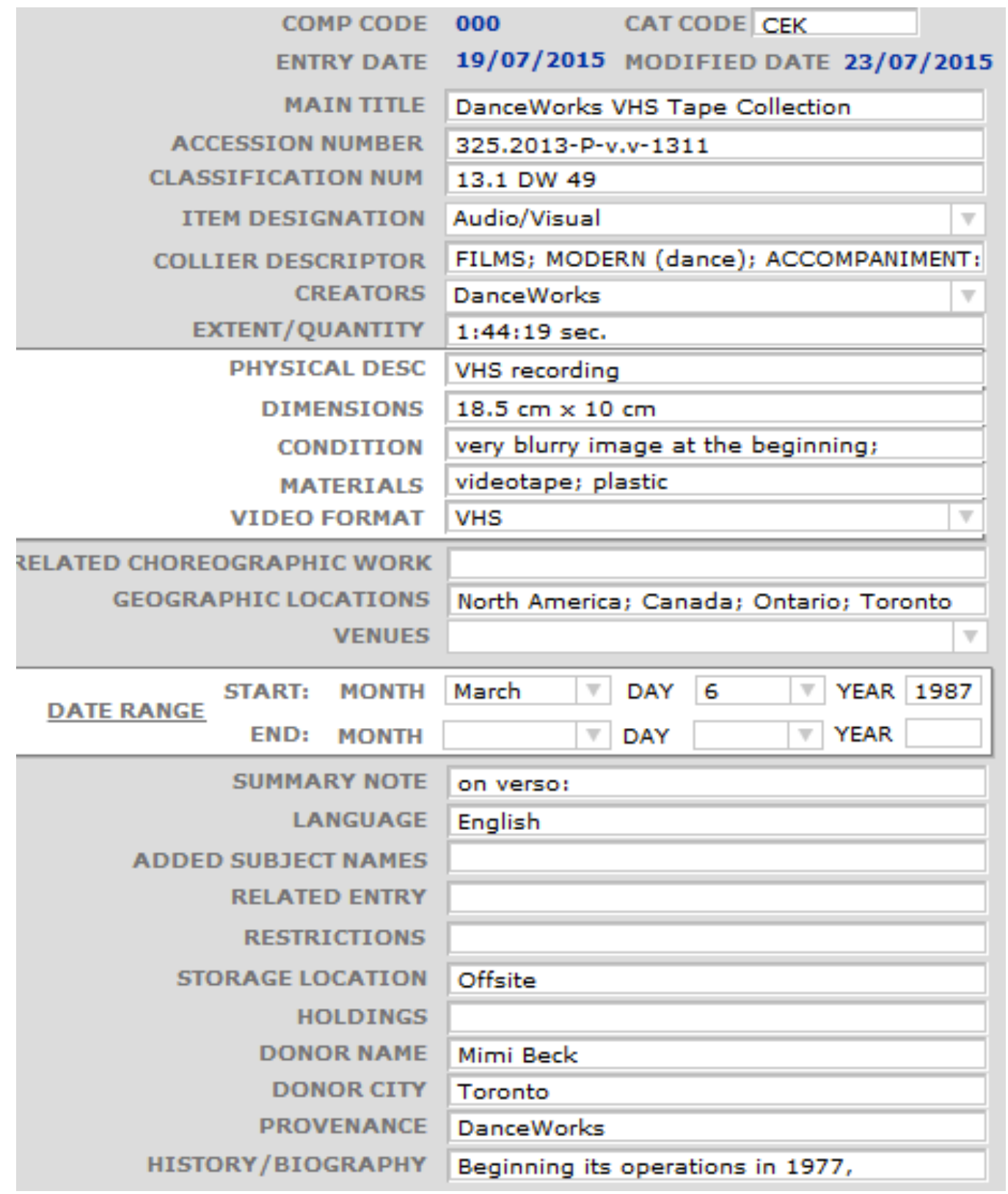




\section{Record 11}

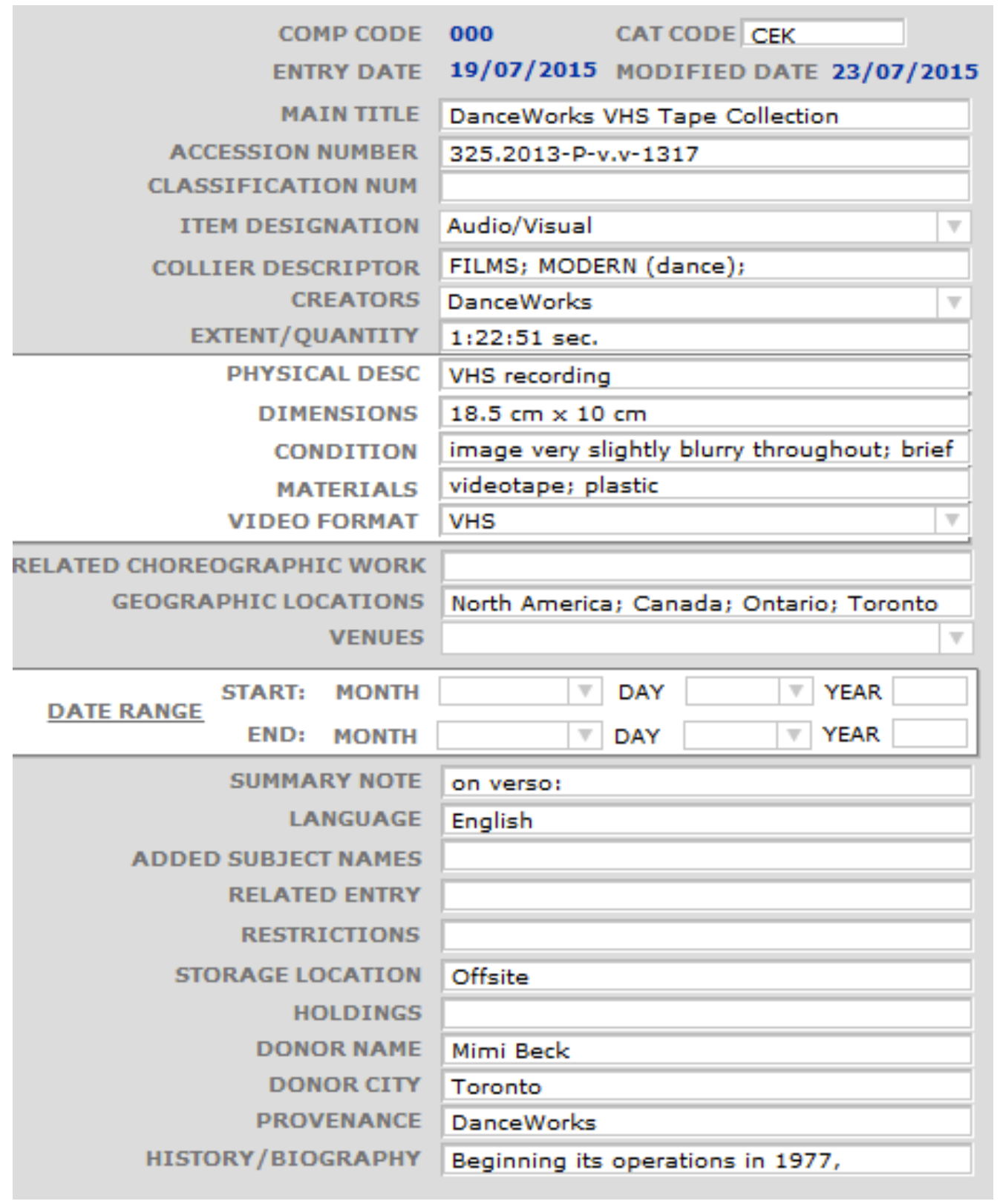




\section{Record 12}

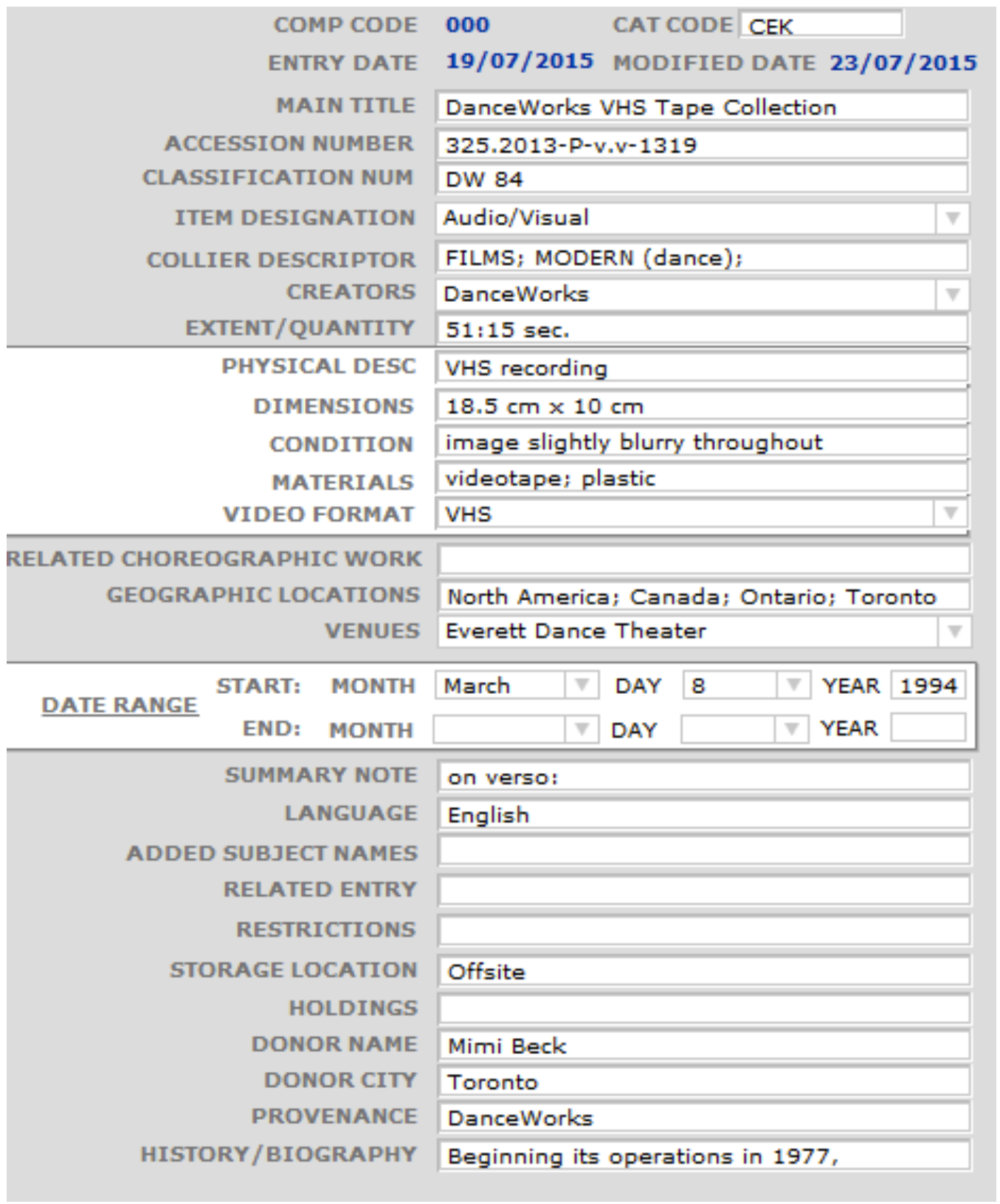




\section{Record 13}

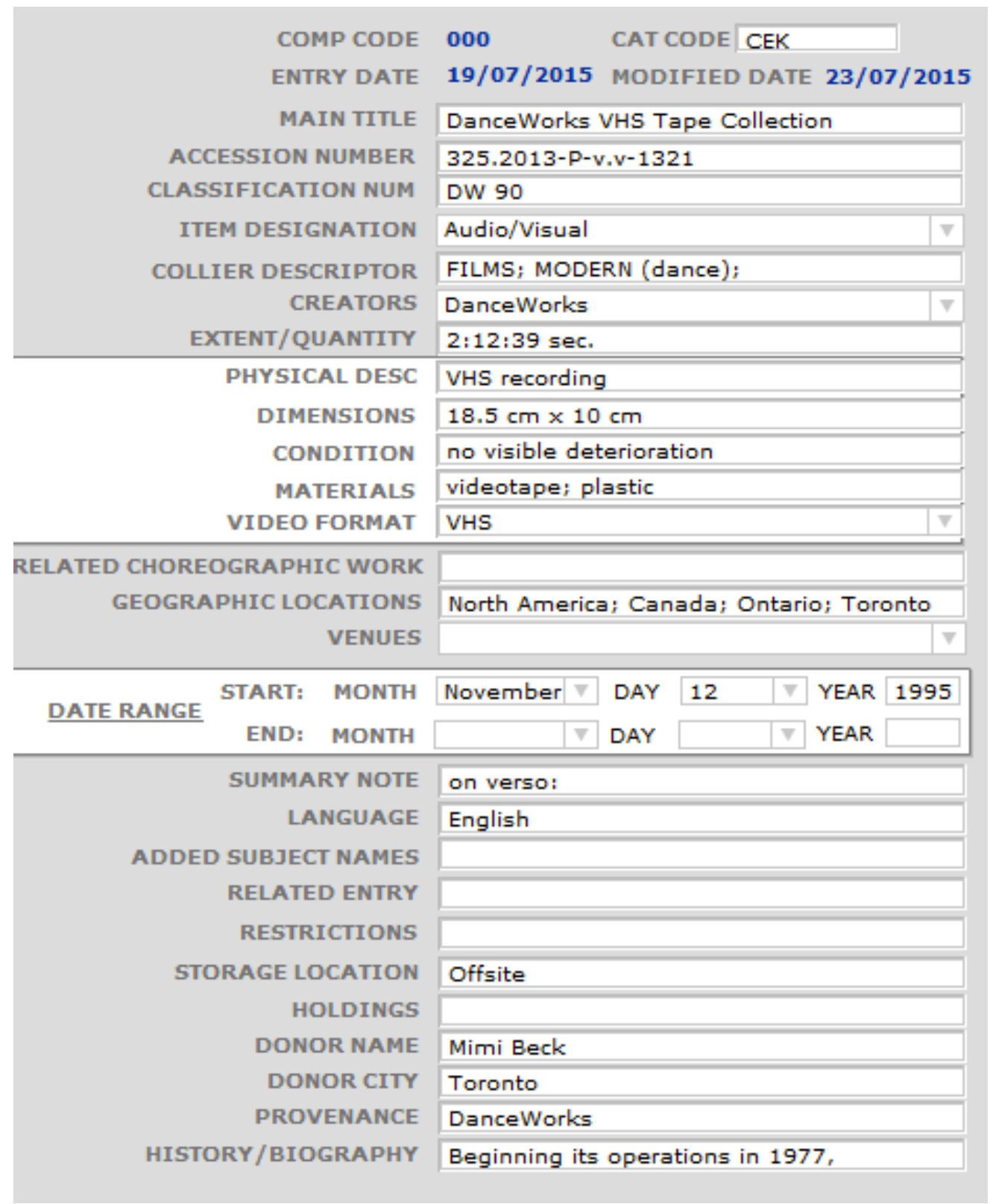




\section{Record 14}

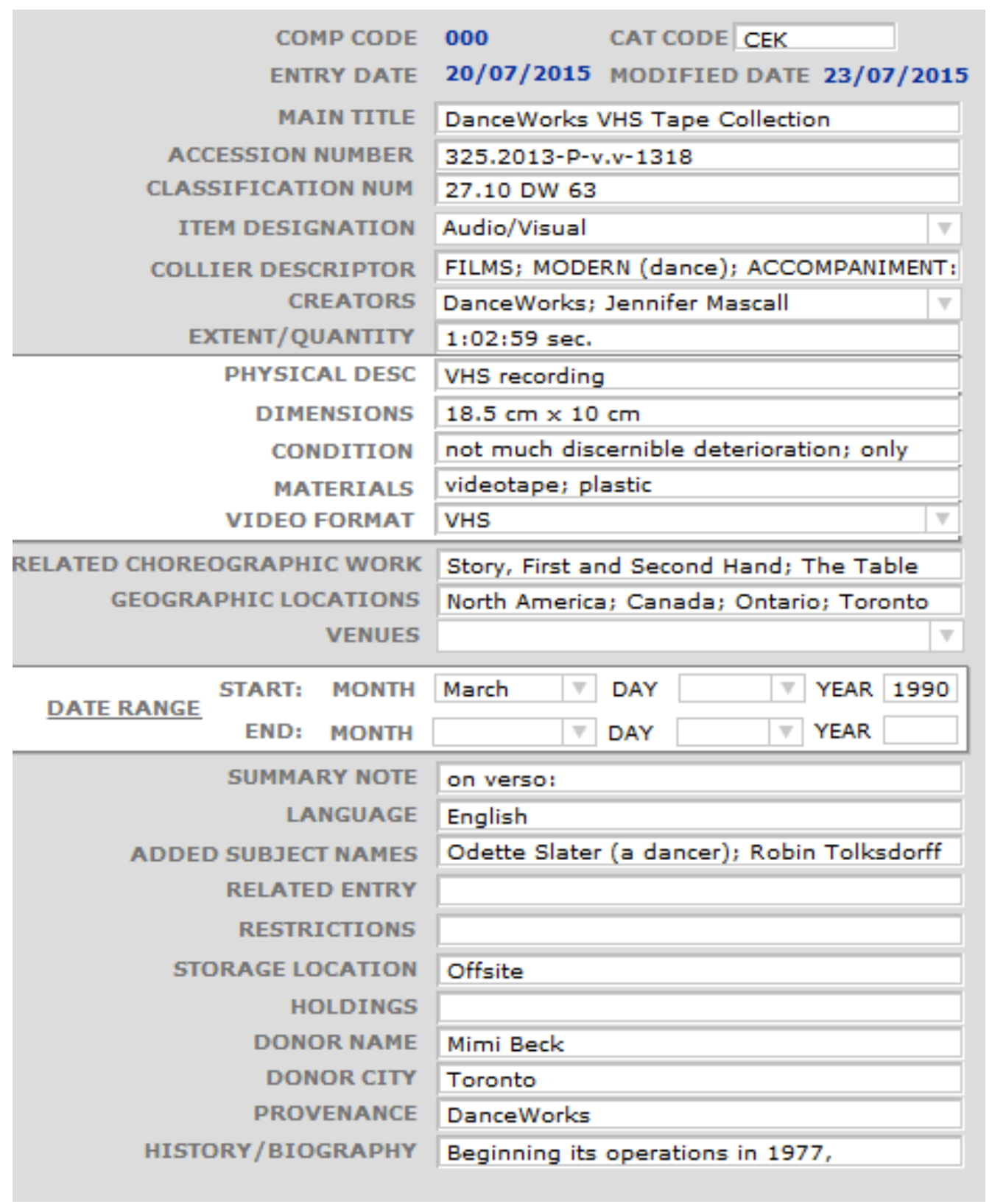




\section{Record 15}

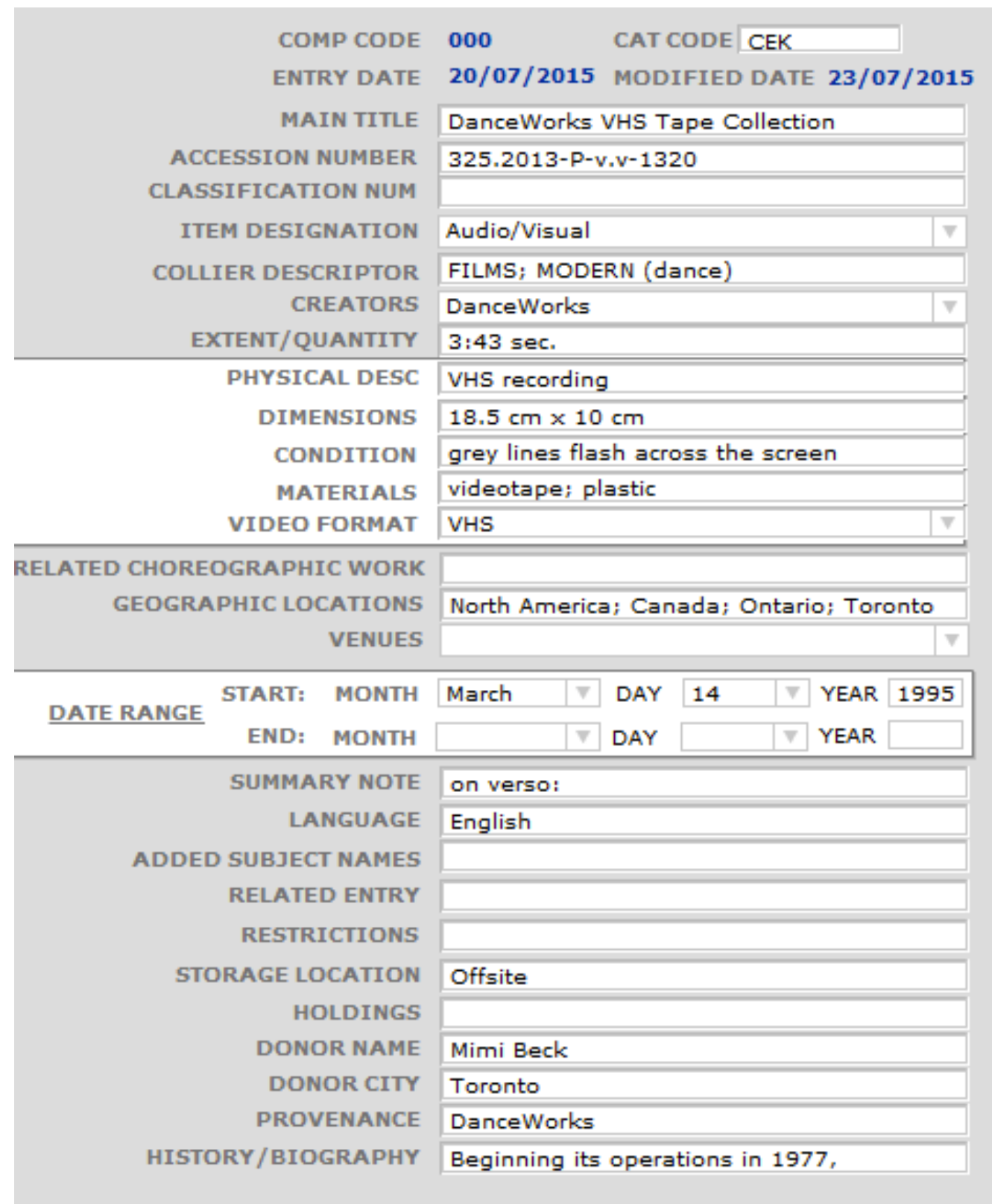




\section{Record 16}

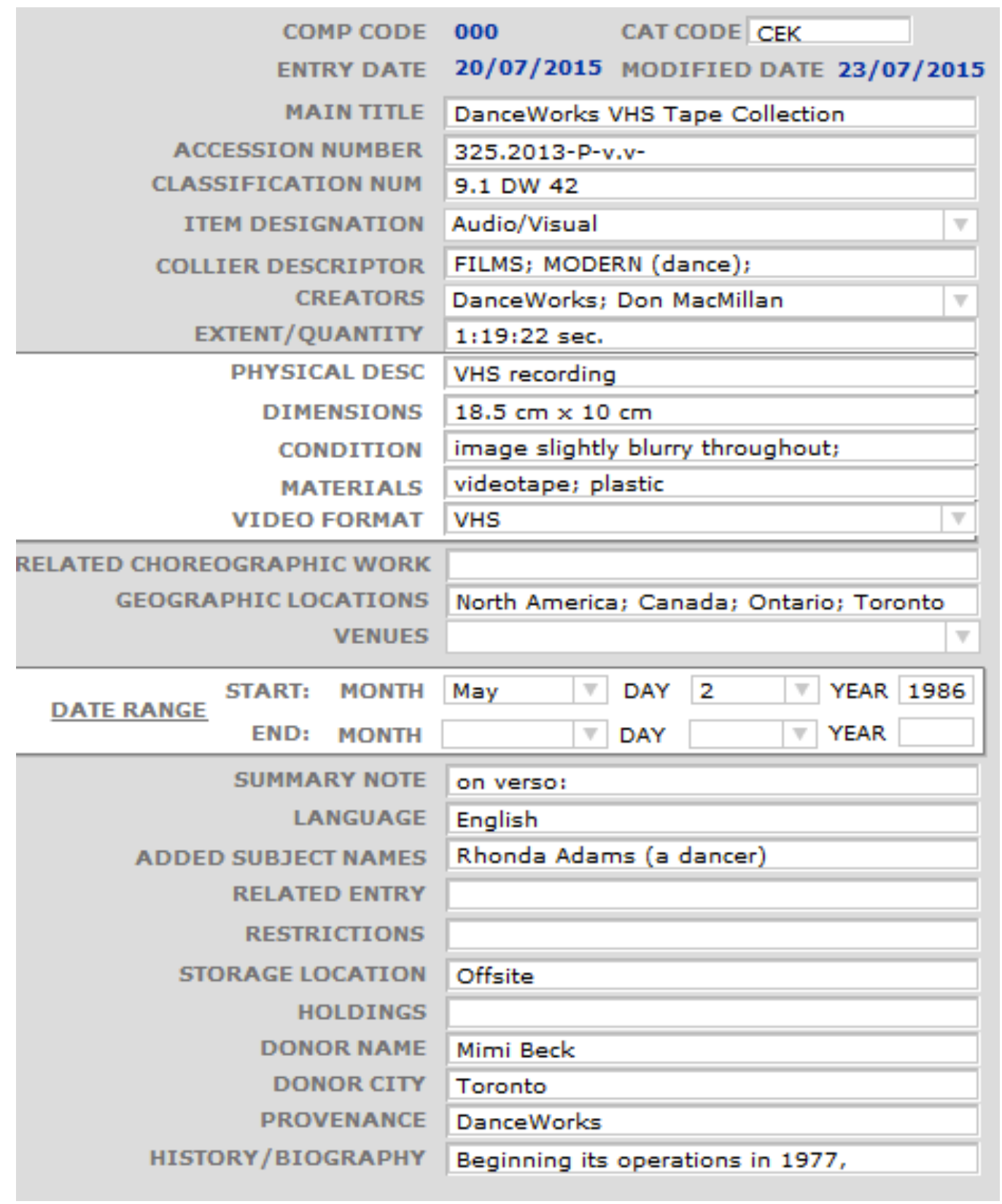




\section{Bibliography}

Adams, Lawrence, Amy Bowring, and Clifford Collier. Canadian Integrated Dance Database Standards Manual and Collier Descriptor Thesaurus, 2008.

"Agent of Deterioration: Incorrect Relative Humidity." Canadian Conservation Institute. Accessed April 1, 2015. https://www.cci-icc.gc.ca/resources-ressources/agentsofdeterioration

“Agent of Deterioration: Incorrect Temperature." Canadian Conservation Institute. Accessed April 1, 2015. https://www.cci-icc.gc.ca/resources-ressources/agentsofdeterioration

"Benefits." Ultrium LTO. Accessed April 1, 2015. http://www.lto.org/solutions/benefits/

“Bill Coleman.” Coleman Lemieux Compagnie. 2013. Accessed July 28, 2015. http://colemanlemieux.com/company/billcoleman/.

Bowring, Amy. "Dance Collection Danse: Canada's Largest Archive and Research Center for Theatrical Dance History.” Dance Chronicle 34, no. 2 (2011): 276-89. Accessed April 1, 2015. doi:10.1080/01472526.2011.580247.

“Canadian Integrated Dance Database." Dance Collection Danse. Accessed April 1, 2015. http://www.dcd.ca/cidd.html

Cornell, Katherine. "DanceWorks At Thirty.” Dance Collection Danse Magazine, 64 (2007): 6-12.

"Dance Collection Danse by the numbers." Publicity Handout. Dance Collection Danse. 2015.

"DanceWorks - About I Background.” DanceWorks. Accessed April 1, 2015. http://danceworks.ca/about/index.html.

"DCD Beginnings." Dance Collection Danse. Accessed April 1, 2015. http://dcd.ca/general/dcdhistory.html

Dodds, Sherril. Dance on Screen: Genres and Media from Hollywood to Experimental Art. Houndmills, Basingstoke, Hampshire: Palgrave, 2001.

Esling, Natalia. "Dance Archives in an Online Environment: The Impact of Digital Media on the Preservation of Dance History." Canadian Theatre Review 156:30-34. Accessed April 1, 2015. doi:10.1353/ctr.2013.0075. 
"Facts About LTO and LTFs." Storage DNA. 2012. Accessed April 1, 2015. http:// www.storagedna.com/media/documents/StorageDNA_whitepaper_Facts-about-LTOLTFS web.pdf.

"FAQ." Ultrium LTO. Accessed April 1, 2015. http://www.lto.org/about-the-lto-program/faq/.

"Federal Libraries, Archives Shutting down." CBC News. May 2, 2012. Accessed April 1, 2015. http://www.cbc.ca/news/canada/ottawa/federal-libraries-archives-shuttingdown-1.1139085.

Harris, Kenton, and David E. W. Fenner. "Video-Preservation of Dance." Journal of Aesthetic Education. 29, no. 1 (1995): 69-78. Accessed January 16, 2015.

“Jennifer Wootton Mascall.” The Canadian Encyclopedia. Accessed July 28, 2015. http://www.thecanadianencyclopedia.ca/en/article/jennifer-wootton-mascall/.

“Judith Marcuse Projects.” Judith Marcuse Projects I ICASC. 2013. Accessed July 28, 2015. http://www.icasc.ca/Judith Marcuse Projects

"Judith Rose Marcuse." The Canadian Encyclopedia. Accessed July 28, 2015. http://www.thecanadianencyclopedia.ca/en/article/judith-rose-marcuse/.

Lindner, Jim. "Magnetic Tape Deterioration: Tidal Wave at Our Shores.” January 1, 1996. Accessed January 16, 2015. http://cool.conservation-us.org/byauth/lindner/tidal.html

"Magnetic Tape and Storage and Handling: A Guide for Libraries and Archives." The Commission on Preservation and Access. June 1995.

"Part 1: Summary of Arts and Culture Budget Reallocations." Parliament of Canada. Accessed June 12, 2015. http://www.parl.gc.ca/HousePublications/Publication

“PPS Danse." The Canadian Encyclopedia. Accessed July 28, 2015. http://www.thecanadianencyclopedia.ca/en/article/pps-danse/.

Rosa, Maria De, Marilyn Burgess, and Philip Szporer. "Canada Dance Mapping Study: Literature Review." Canada Council for the Arts. 2012.

Rowat, Theresa. "Dance Heritage and Current Status." Prepared for the Dance Advisory Committee and The Canada Council of Arts, May 28 2003. Accession number: 019. 2008 $-1-24$.

Rowat, Theresea. "Study of dance collections in Canada." Commissioned by the Dance Section of the Canada Council, with the participation of the Department of Canadian Heritage (Arts and Heritage Sector). Login:danc/se circulation draft. 2000. Accession number: 019. $2008-1$ - 24. 
Siegel, Marcia B. "Introduction." At the Vanishing Point: A Critic Looks at Dance. New York: Saturday Review Press, 1972.

Smith, Kathleen M. "Saving The Past for The Future.” The Dance Current 13 no. 8, March 23, 2011.

"The Company - PPS Danse." PPS Danse. 2015. Accessed July 28, 2015. http://ppsdanse.com/en/the-company/.

"The Preservation of Magnetic Tape Collections: A Perspective." National Endowment for the Humanities Division of Preservation and Access. December 22, 2006. Accessed April 1st, 2015.

Williams, Anne-Marie. "Dance in the Digital Age." The Dance Current 11 no. 3, September 30, 2008. 